\title{
Liderlik ve Okul Etkililiği Düzeyleri Arasındaki İlişki: Bir Meta Analiz Çalışması
}

\author{
Hanifi Yumuşak \\ Millî Ĕ̆gitim Bakanlığg \\ Mehmet Korkmaz \\ Gazi Üniversitesi, Eğitim Fakültesi
}

ÖZ

Okulun gelişimi ve etkililiği konusunda okul yöneticisinin formal ve informal liderlik özellikleri büyük bir öneme sahiptir. Bu doğrultuda, ilgili çalışmada liderlik ve okul etkililiği düzeyleri arasındaki ilişkinin meta-analiz yöntemi ile ortaya konması amaçlanmıştır. Bu amaç doğrultusunda liderlik ve okul etkililiği düzeyleri arasındaki ilişkileri inceleyen çalışmaların etki büyüklükleri arasında alt grup (moderatör) değişkenlere göre anlamlı bir farklılık olup olmadığ incelenmiştir. 2010-2020 yılları arasında liderlik ve okul etkililiği düzeyleri arasındaki ilişkiyi inceleyen, örneklem sayısı ve korelasyon katsayısı verilerini içeren çalışmalar araştırmaya dâhil edilmiştir. Araştırma kapsamındaki çalışmalara, ulusal ve uluslararası veri tabanları kullanılarak ulaşılmıştır (Ulusal Tez Merkezi, Web of Science (WOS), Education Resources Information Center (ERIC), Scopus, EBSCOhost, vb.). Alan yazın taraması sonucunda araştırmanın seçim ölçütlerine uygun 22 çalışma meta-analize dâhil edilmiştir. Araştırmada etki büyüklüğü değerlerinin hesaplanmasında "Fisher Z" değeri kullanılmıştır. Araştırma kapsamındaki çalışmaların birleştirilmiş etki büyüklüğü rastgele etkiler modeline göre hesaplanmıştır. Analiz sonucunda, liderlik ve okul etkililiği düzeyleri arasındaki ilişkinin genel etki büyüklüğünün pozitif yönlü ve yüksek düzeyde olduğu ortaya konmuştur. Ayrıca liderlik ve okul etkililiği düzeyleri arasındaki ilişkileri inceleyen çalışmaların etki büyüklükleri arasında moderatör değişkenlere (çalışmanın yapıldı̆̆ı bölge, okul kademesi ve liderlik türleri) göre anlamlı bir farklılaşmanın olduğu görülmüştür. Araştırma kapsamında okulların etkililik düzeyini artırmak için okul yöneticilerinin öğretim süreç ve amaçları konusunda gelişimlerinin desteklenmesi önerilmektedir.

Anahtar Kelimeler: Liderlik, okul etkililiği, meta-analiz.

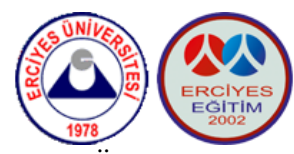

Erciyes Üniversitesi, Eğitim Fakültesi, Kayseri/TÜRKIYE

Erciyes Journal of

Education (EJE)

DOI: $10.32433 /$ eje. 980997

SCREENED BY

iThenticate

Tür: Araştırma

Makale Geçmişi

Gönderim : $\quad$ 10.08.2021

Kabul : $\quad 25.10 .2021$

Yayınlanma : 26.10.2021

Önerilen Atıf

Yumuşak, H. ve Korkmaz, M. (2021). Liderlik ve okul etkililiği düzeyleri arasındaki ilişki: bir meta analiz çalışması. Erciyes Journal of Education, 5(2), 121-148. https://doi.org/10.32433/eje.980997

1. Dr. Öğrencisi, Eğitim Bilimleri Bölümü, Eğitim Yönetimi ABD, hanifiyumusak@gmail.com, https://orcid.org/00000003-3600-2561

2. Prof. Dr., Eğitim Bilimleri Bölümü, Eğitim Yönetimi ABD, korkmaz@gazi.edu.tr, https://orcid.org/0000-0001-76005121 


\title{
The Relationship Between Leadership and School Effectiveness Levels: A Meta-Analysis Study
}

\author{
Hanifi Yumuşak \\ Ministry of Education \\ Mehmet Korkmaz \\ Gazi University Faculty of Education
}

\begin{abstract}
Formal and informal leadership characteristics of the school administrator have a great importance in the development and effectiveness of the school. In this direction, it is aimed to examine the relationship between leadership and school effectiveness levels with the meta-analysis method. For this purpose, it has been investigated whether there is a significant difference between the effect sizes of the studies examining the relationships between leadership and school effectiveness levels according to the moderator variables. The studies examining the relationship between leadership and school effectiveness levels in the years 20102020 including the number of samples and correlation coefficient were included in the study. The studies within the scope of this study were accessed by scanning in national and international databases (Council of Higher Education Thesis Center, Web of Science, Education Resources Information Center (ERIC), Scopus, EBSCOhost, etc.). As a result of the literature review, 22 studies that were following the selection criteria of the research were included in the meta-analysis. In the study, "Fisher's Z" value was used to calculate the effect size values. Overall effect size of the studies within the scope of the study were calculated according to the random-effects model. As a consequence of the analysis, it was found that the overall effect size of the relationship between leadership and school effectiveness levels was positive directional and stronge. Moreover, it was observed that there was significant difference between the effect sizes of the studies examining the relationships between leadership and school effectiveness levels according to the moderator variables (location of the study, type of school and leadership types). Supporting the development of school administrators on teaching processes and objectives will increase the effectiveness of schools.
\end{abstract}

Keywords: Leadership, school effectiveness, meta-analysis.

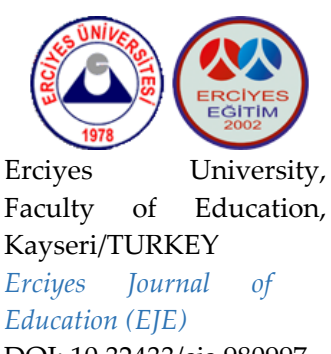

DOI: $10.32433 /$ eje.980997

\section{SCREENED BY}

\section{iThenticate}

Type: Research

Article History

Received : 10.08.2021

Accepted : 25.10.2021

Published : 26.10.2021

\section{Suggested Citation}

Yumuşak, H. and Korkmaz, M. (2021). The relationship between leadership and school effectiveness levels: A metaanalysis study. Erciyes Journal of Education, 5(2), 121-148. https://doi.org/10.32433/eje.980997

1. PhD student, Educational Sciences Department, Educational Administration, hanifiyumusak@gmail.com, https://orcid.org/0000-0003-3600-2561

2. Prof. Dr., Educational Sciences Department, Educational Administration, korkmaz@gazi.edu.tr, https://orcid.org/ 0000-0001-7600-5121 


\section{EXTENDED ABSTRACT}

\section{Introduction}

A lot of research has been done and is still being done in the context of school effectiveness or effective schools. When these studies are examined, it is seen that the concept of school effectiveness has been intensively studied with subjects such as leadership behaviors and leadership types (Atılkan, 2019; Cheng, 1997; Hallinger ve Heck, 1999; McNamara, 1968; Namlı, 2017; Y1lmaz, 2010). Studies on the subject have indicated that there is a significant relationship between school principals' leadership behaviors and school effectiveness (Balc1, 2002; Şişman, 2020; Tatlah ve Iqbal, 2012). The behavior of school leaders has a significant impact on school effectiveness, and in recent years, efforts have been made to increase school effectiveness by creating an effective school environment and factors such as school leaders have been emphasized (Arslantaş ve Özkan, 2014; Laila, 2015; OECD, 2018). Because both leadership and school effectiveness phenomena keep up-to-date and have very important results for both the individual and the organization.

\section{Purpose}

In this study, it is aimed to combine the results of the study conducted on the relationship between leadership and school effectiveness and to determine the total effect size. No other metaanalysis study investigating the relationship between leadership and school effectiveness by including meta-analyse them has been found in the national literature. In order to achieve this goal, answers to the following questions were sought:

1.) What is the overall effect size of the relationship between leadership and school effectiveness levels?

2.) In the literature, is there a significant difference between the effect sizes of studies examining leadership and school effectiveness levels according to moderator variables (the type of publication, location of the study, type of school, leadership types used in the studies and type of scales used in the study)?

\section{Method}

The method of this research is to examine the effect level of the relationship between leadership and school effectiveness by using meta-analysis. Meta-analysis aims to obtain a general result by synthesizing data from different studies containing similar data on the same subject under a single study and means statistically combining the results of related studies (Borenstein vd., 2013).

\section{Findings}

Within the study's scope, 22 results were obtained published in Turkey, examining the relationship between leadership and school effectiveness. Fifteen of these studies are in the form of thesis work, and seven are in the article. One of the most critical factors that can affect the result in a meta-analysis study is publication bias. According to the Funnel Plot, Classic Fail-Safe N 
statistic and Begg and Mazumdar Rank Correlation Statistics, which were made to determine whether publication bias exists, there is no publication bias in our study data.

The first finding of the study showed that there was a strong and positive relationship between leadership and school effectiveness levels. According to Şişman (2018), studies in the field of educational administration show that leadership behaviors have a critical importance in the development and improvement of the school. The second finding of the study revealed that there was no significant difference between the effect sizes of the studies examining leadership and school effectiveness levels according to the moderator variables (the type of publication, location of the study, type of school, leadership types used in the studies and type of scales used in the study). It was observed that there was significant difference between the effect sizes of the studies examining the relationships between leadership and school effectiveness levels according to the moderator variables (location of the study, type of school and leadership types used in the studies).

\section{Discussion \& Conclusion}

As a result, it has been revealed that there is a positive and strong relationship between leadership and school effectiveness. In this context, the leadership characteristics of the school administrator are of great importance for schools to offer more successful outputs. In this direction, it can be recommended that policymakers focus on the selection of administrators and training practices in the administrative arrangements to be made for schools. In addition, it indicates that there is a significant differentiation in terms of moderator variables (region where the study was conducted, school level and leadership types) revealed within the scope of our research. In light of this information, if special emphasis will be given to instructional leadership, one of the leadership types, and supporting the development of school administrators in terms of teaching processes and objectives will increase the effectiveness of schools. But, it is not possible to reveal the reasons for this differentiation in more detail and in depth through quantitative research. It will contribute to the literature that researchers who will work on this subject in the future focus on the reasons for this difference between school types. 


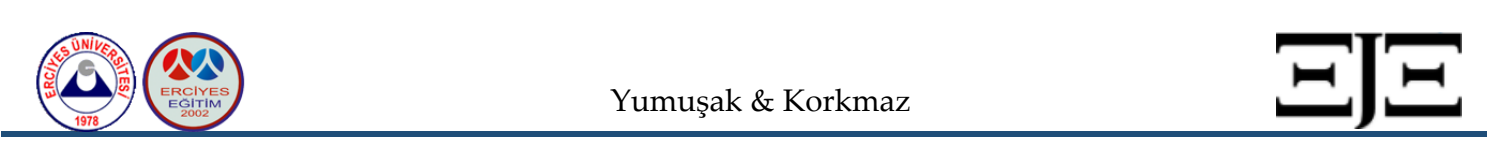

Erciyes Journal of Education 2021, Vol 5, No 2, 121-148

\section{GíRiş}

Öğrencilerin akademik ve sosyal başarılarına etki eden unsurları ortaya koymak için pek çok araştırma yapılmıştır. Bu araştırmalar incelendiğinde genel olarak bu unsurlar; öğrencinin kendisi, ailesi ve okul olarak üç başlık altında ifade edildiği görülmektedir (Çobanoğlu ve Badavan, 2016; Dağdelen, 2013; Engin vd., 2009; Özer ve Anıl, 2011; Polat, 2009). Bu unsurlar incelendiğinde birey ve ona ait özellikler dışındaki en önemli belirleyici okuldur. Bu doğrultuda okula ilişkin boyutları ortaya koymak için çeşitli araştırmalar yürütülmüştür. Bu çalışmalarda özellikle okul etkililiği kavramı (Guthrie, 1970; Levin, 1970; McNamara, 1968; Reynolds, 1985; Sammons vd., 1995) ön plana çıkmış ve etkili okulların özelliklerini belirlemek için pek çok model ortaya konmuştur. Ancak kavramın çok katmanlı yapısı nedeni ile üzerinde tam bir uzlaşma sağlanamamışır. Bu nedenle gerek konunun önemi gerekse çok katmanlı yapısı nedeni ile okulların etkililiği, etkilediği ve etkilendiği faktörler araştırmalara konu olmuş ve günümüzde de araştırılmaya devam edilmektedir. Amerika Birleşik Devletleri'nde (ABD) Coleman vd. (1966) yapmış olduğu araştırma okul etkililiği araştırmalarına kaynaklık yapan ilk çalışmadır (Şişman, 2020), ilgili çalışma okul etkililiği açısından milat olarak kabul edilirse yaklaşık elli yıldır kavram üzerinde yoğun bir şekilde çalışıldığı görülmektedir.

Okul etkililiği veya etkili okullar bağlamında pek çok araştırma yapılııs ve hâlen yapılmaktadır. Bu çalışmalar incelendiğinde okul etkililiği kavramının liderlik davranışları ve liderlik türleri (Attlkan, 2019; Cheng, 1997; Hallinger ve Heck, 1999; McNamara, 1968; Namlı, 2017; Yılmaz, 2010) gibi konular ile yoğun bir şekilde çalışıldığı görülmektedir. Bir okulun amaçlarına ulaşmasında kilit kavramlarından biri de liderin rolüdür. Lider eğitim yönetiminin ana unsurlarının birini oluşturmaktadır. Okulun formal lideri olarak müdür, kurumunda uygun eğitim atmosferinin oluşmasında ve eğitimsel başarının yakalanmasında başat bir role sahiptir (İnce, 2017). Konuyla ilgili yapılan araştırmalar okul yöneticilerinin liderlik davranışları ile okul etkililiği arasında anlamlı bir ilişki olduğunu belirtmişlerdir (Balcı, 2002; Şişman, 2020; Tatlah ve Iqbal, 2012). Okul liderlerinin davranışlarının okul etkililiği üzerinde önemli bir etkisi vardır ve son yıllarda etkili bir okul ortamı yaratarak okul etkililiğini artırmak için yapılan çalışmalar okul lideri gibi faktörler üzerinde fazlaca durulmaktadır (Arslantaş ve Özkan, 2014; Laila, 2015; OECD, 2018). Liderlik ve okul etkililiği arasındaki ilişkileri açıklamaya çalışan çok sayıda çalışma bulunmakla birlikte çalışma sayısı her geçen gün artmaktadır (Abdurrezzak, 2015; Atılkan, 2019; Bolanle, 2013; Cansoy ve Parlar, 2018; Nartgün, Limon ve Dilekçi, 2020; Tatlah ve Iqbal, 2012; Yilmaz, 2010).

İlgili alan yazın incelendiğinde hem liderlik hem de okul etkililiği olguları güncelliğini korumakla birlikte hem birey için hem de örgüt için çok önemli kavramlar olduğu görülmektedir. Söz gelimi 2010-2020 yılları arasında sadece Social Sciences Citation Index (SSCI), Emerging Sources Citation Index (ESCI) gibi Web of Science (WOS) index kapsaminda taranan kaynaklar incelenmiştir. Sonuçlar incelendiğinde tüm konu başlıklarında "okul etkililiğ̈i" konusunu içeren bin elli sekiz adet $(\mathrm{n}=1058)$ yayın üretildiği belirlenmiştir. Bu yayınların ise yedi yüz üç adedinin $(n=703, \% 66,44)$ eğitim alanı konu başlı̆̆ altında üretildiği ve yıllar arasında yayın üretimindeki varyansın düşük olduğu yani yayın sayısı açısından istikrarlı bir biçimde yayın üretildiği görülmektedir (WOS, 2020). 
İlgili alan yazın incelendiğinde, okul lideri olarak müdürler, etkili politikaların uygulanmasının anahtarı olarak kabul edilir (Altun ve Sarpkaya, 2017; Hallinger and Walker, 2017). Kochamba and Murray'e (2008) göre (aktaran Bolanle, 2013) okulun etkililiğini sağlayabilmelerinde okul yöneticisinin teknik, insan ilişkileri ve dönüşümsel liderlik gibi kritik becerilere sahip olmaları büyük bir önem taşımaktadır. Laila'nın (2015) yaptı̆̆ı çalışmada öğretmenlere göre okulun etkililiği için okul liderleri, okul içi moral gücü yüksek tutmalı, bir öğrenme toplumu oluşturmalı, elindeki fiziksel ve finansal kaynakları büyük bir özen ve etkililikle kullanmalıdır. Cansoy ve Parlar (2018) ise farklı bir perspektifle öğretmen liderliği üzerinde durarak öğretmen liderliği ve okul etkililiği arasında güçlü ve istatistiksel olarak anlamlı bir ilişki olduğunu ortaya koymuştur. Bu doğrultuda, pekçok farklı bakış açısı ile okul etkililiği kavramının liderlik yaklaşımları ile ele alındığı görülmektedir. Liderlik sadece idari bilimler ve iş hayatında değil, psikoloji, sosyoloji ve benzeri alanlarda da karşılaşılmaktadır (Şişman, 2018). Bu nedenle her alanın öncelikleri farklı olduğu için liderliğin ortak bir tanımı yoktur (Çogaltay, Yalçın ve Karadağ, 2016). Bu bağlamda alan yazın incelendiğinde farklı bakış açıları ve yaklaşımlar ile çalışmaların yürütüldüğü görülmektedir. Liderliği; bir kişi ya da grubu ortak bir amaç için işe koşabilme, etkileme yeteneği olarak düşünürsek mevcut araştırma, genel olarak liderliğin okul etkililiği ile olan ilişkisini ve farklı bakış açılarını sentezleyerek bütüncül bir bakış açısı sağlayacaktır.

Bu bağlamda ilgili literatür ışığında, liderlik ve okul etkililiği arasındaki ilişkileri inceleyen çalışmaların sonuçları birleştirilerek bir meta-analiz çalışması yapılması ihtiyacı önem arz etmektedir. Liderlik ve okul etkililiği ile ilgili bir meta-analiz çalışmasının yapılması, liderlik ve okul etkililiği arasındaki ilişkinin gücünü ve yönünü daha kapsamlı bir şekilde belirlemek açısından önemlidir. Ayrıca liderlik ve okul etkililiği arasındaki ilişki üzerinde etkisi bulunduğu düşünülen çeşitli moderatör değişkenler (yayın türü, [örneklem] bölgesi, okul kademesi, liderlik türü ve ölçek [okul etkililiği] türü) kullanılarak alt grup analizler yapılacak ve bu değişkenlerin ortaya koyduğu sonuçlar alan yazına önemli bilgiler sağlayacaktır. Bu bilgiler ışığında, liderlik ve okul etkililiği arasındaki ilişki ve bu ilişkide değişime sebep olan faktörler ortaya konularak bu bağlamda okullar ve politika yapıcılar açısından kanıtlar sunacaktır. Ayrıca mevcut konu kapsamında ileride yapılacak çalışmalar için araştırmacılara bir perspektif sunarak literatüre katkı sağlayacağı öngörülmektedir. Bu çalışmanın amacı, liderlik ve okul etkililiği arasındaki ilişkinin incelendiği çalı̧̧maların toplam etkisinin meta-analiz yöntemi ile incelenmesidir. $\mathrm{Bu}$ amaç çerçevesinde aşağıdaki problemlere cevap aranmıştır.

1.) Liderlik ve okul etkililiğgi arasındaki ilişkinin birleştirilmiş etki büyüklüğü düzeyi nedir?

2.) Liderlik ve okul etkililiği arasındaki ilişkileri ortaya koyan çalışmaların etki büyüklükleri arasında moderatör (alt grup) değişkenlere (yayın türü, çalışma [örneklem] bölgesi, okul türü, liderlik türü ve ölçek [okul etkililiği] türü) göre istatistiksel olarak anlamlı bir farklılaşma var mıdır?

\section{Okul Etkililiği}

Amerika Birleşik Devletleri'nde (ABD) Coleman ve arkadaşları (1966) tarafından yapılan çalışmanın, okulların etkileri ve okul etkililiği açısından kabul edilecek ilk çalışma olduğu söylenebilir. Eğitimde firsat eşitliğ araştırmada öğrencinin başarısını belirlemede okula kaynaklı değişkenlere göre öğrencinin aile 
geçmişi ve sosyal bağlam gibi diğer özelliklerin daha etkili olduğu ifade edilmiştir (Lunenburg ve Ornstein, 2013).

Brookover ve diğerleri (1977), Coleman vd. (1966) raporunun zittı yönde sosyal sistem değişkenlerinin birleşiminin öğrenci başarısında meydana gelen değişimin \%85'ini açıkladığını iddia etmiştir (Brookover vd. 1977, aktaran Harbaugh, 2005). "Neden bazı okullar diğer okullara göre daha yüksek öğrenci başarısına sahiptir?" sorusunun cevabını arayan çeşitli araştırmalar yürüten Edmonds, "Search for Effective Schools (Etkili Okullar Araştırması)" araştırmasını bitirdikten sonra Edmonds (1979) etkili okulların özelliklerini; güçlü liderlik, hiçbir çocuğun akademik açıdan minimum seviyenin altına düşmesine izin verilmeyen bir iklim, öğretim işlevine göre hazırlanmış uygun çevre, okuldaki kaynakların temel amaca hizmet edecek şekilde kullanımı, öğrencideki değişim ve gelişimin düzenli olarak gözlenmesi (bireyselleştirilmiş öğretim ve periyodik değerlendirme) ve öğrencilerin temel düzeydeki yeterlikleri ve becerileri edinmelerine öncelik verme şeklinde belirtmiştir.

Okulun etkililiğinin tanımlanması konusunda ortak bir görüş oluşmadığı için bazıları birbiri ile binişik olan pek çok tanım yapılmıştır: problem çözen okul (Reid vd., 1987), "öğrencilerin bilişsel, duyuşsal, psiko-motor, sosyal ve estetik gelişimlerinin en uygun biçimde desteklendiği, optimum bir öğrenme çevresinin yaratıldığ1 okul" (Özdemir, 2000, s.36), sürekli öğrenen ve gelişen örgüt olarak okul (Günal, 2014) ve "okulun hedeflerini gerçekleştirmesi" (Lezotte, 1993, s.22). Etkili okul kavramı ile ilgili araştırmacıların üzerinde ittifak ettiği ortak bir tanım yapılamamıştır. Örgütler açısından bakıldığında etkililik, amaçların gerçekleşme derecesi ve sonuçlar bağlamında değerlendirilmektedir (Şişman, 2020) fakat okulları diğer örgütlerden ayıran en önemli özellik ürünün insan odaklı olması, ürünün daha çok soyut duyuşsal ve aynı zamanda bilişsel değerler ile yüklü olması çıktıları yoruma açık hâle getirmektedir. Bu bağlamda etkili okulun ölçümüne aracılık edecek kavramlar, değişkenler ve göstergelere ancak bir kuramsal temel vasıtasıyla (Hoy ve Ferguson, 1985) ulaşılabileceği ifade edilmiştir. Bu noktadan hareketle amaç modeli, kaynak-girdi modeli, süreç modeli, doyum modeli ve toplam kalite modeli (Cheng, 1996, s.19) gibi birçok model ortaya konmuştur.

Okul etkililiği kavramının tanımlanması ve ilişkiler ağının belirlenmesi açısından geçen yaklaşık elli yıldan beri eğitim araştırmacıları açısından konu merkezi ve başat rolünü kaybetmemiş ve birçok kuramsal (Balcı, 2002; Marzano, 2012; Sergiovanni, 2006; Şişman, 2020) çalışma yapılmıştır. Bunun yanısıra okul etkililiği kavramının etkilediği ya da etkilendiği faktörleri belirlemek için pozitif psikolojik sermaye (Çiftçi, 2019), liderlik ve liderlik stilleri (Baştoklu, 2015; Ermeydan, 2019; Namlı, 2017), örgütsel iklim (Özgenel, 2020; Şenel ve Buluç, 2015), akademik başarı (Korkmaz vd., 2014; Oldaç, 2016), örgütsel öğrenme (Akgül, 2014; Alanoğlu, 2014) gibi birçok ampirik araştırmanın yapıldığı görülmektedir.

Yukarıda okul etkililiğinin kuramsal temellerine ilişkin sunulan açıklama ve tanımlamalar, okul etkililiğinin öğretimin niteliğini ve akademik başarıyı artırmaya dönük bir kavram olduğunu göstermektedir. Okul etkililiğine ilişkin pek çok farklı bakış açısı olsa da hangi perspektifle bakılırsa bakılsın doğrudan ya da dolaylı olarak okul etkililiğinin öğrencinin akademik ve sosyal açıdan iyi oluş hâlini olumlu şekilde etkilediğini söyleyebiliriz.

\section{Liderlik}

Liderlik insanlık tarihi boyunca, insanın sosyal bir varlık olarak birlikte yaşama gereksinimi sonucu ortaya çıkan köklü bir kavramdır. Liderlik; içinde yaşanılan durum, kültür, sosyo- 
ekonomik nedenler gibi birçok faktörden etkilenerek içerik ve anlam bakımından sürekli değişime uğramış bir kavramdır (Özkan, 2016). Örneğin liderler, yaşadıkları kültürel çevrenin kodları çerçevesinde hareket ettikleri için farklı kültürlerde farklı liderlik tarz, tutum, davranış ve özellikleri ortaya çıkmıştır (Yeşil, 2013). Sadece kültürel açıdan değil bilimsel alanlarda da farklılık gösteren liderlik, sadece yönetim bilimlerinin değil psikoloji, sosyoloji ve benzeri alanların da bir çalışma alanı olarak karşımıza çıkmaktadır (Şişman, 2018). Bu doğrultuda liderlik farklı alanlarda farklı yaklaşım ve bakış açıları ile ele alınmıştır. Bunun bir sonucu olarak her alanda öncelikler farklılaşmış ve liderliğin ortak bir tanımı yapılamamış (Çoğaltay vd., 2016) veya farklı disiplinler, farklı anlamlar yükleyerek liderliği tanımlamaya çalışmıştır (Turan ve Bektaş, 2014).

Bu bağlamda liderlik, daha çok tanımlar üzerinden değil liderliğin ne olduğunu açıklamaya dönük yaklaşımlar üzerinden ele alınmaktadır. Bunlar; özellikler yaklaşımı, davranışsal yaklaşımlar, durumsal yaklaşımlar ve son dönemde yoğun bir şekilde üzerinde durulan çağdaş yaklaşımlar olarak ifade edilebilir (Küçüközkan, 2015). Liderlik kavramının tartışıldığı ilk dönemlerde daha çok liderin sahip olduğu özellikleri üzerinde durulmuş ve liderlik; fiziksel, psikolojik ve bilişsel özellikler üzerinden incelenmiştir (Sönmez, 2017). Daha sonra liderin sergilemiş olduğu davranışlar üzerinde durularak bu davranışların geliştirilebilir bir yapıda olup olmadığı tartışılmıştır (Özkan, 2016). Diğer bir yaklaşım ise liderin karşılaştığı duruma göre hareket etmesi gerektiğini söylemektedir. Bir başka deyişle ayn liderlik özelliğinin, her duruma uygun olmadığını ifade eder (Yukl, 2010). Sonuç olarak liderlik farklı bakış açılarından ele alındığında, farklı şekillerde incelenen, tanımlanabilen ve ortaya çıkan muğlak, çelişkili ve karmaşık bir olgu ve kavramdır (Turan, 2020). Liderliği genel olarak bir sosyal etkileme süreci (Yukl, 2010) ya da "ortak amaçları gerçekleştirmek için kişileri, grupları etkileme ve yön verme süreci" (Turan, 2020, s.5) olarak ifade edilebilir.

Liderlik, diğer sosyal bilimler alanında olduğu gibi eğitim bilimlerinde de yüksek bir oranda karşılık bulmuştur. Özellikle etkili ve başarılı okullarda okul yöneticisinin liderlik rolleri üzerine yapılan tartışmalar ve araştırmalar, liderlik kavramını eğitim alanında gündemde tutmaktadır (Şişman, 2018). Bu bağlamda eğitim kurumlarının çeşitli kademelerinde görev yapan yöneticiler ve onların liderlik tarz, davranış ve özelliklerine ilişkin araştırmalar yürütülmektedir. Özellikle de bu çalışmaların okul yönetimi ve çalışanlar üzerinde çeşitli güç türlerini harekete geçirme kabiliyetine sahip olan okul müdürleri üzerinde yoğunlaştığı söylenebilir. Bu bağlamda okul liderlerinin, okul ve okula ait değişkenler üzerindeki çok yönlü etkisini ortaya koymak için liderlik tarzları ve bu liderlik tarzlarının etkileşim içerisinde olduğu pek çok kavramla ile ilgili çalışma yürütülmüştür. Örneğin, liderlik ve okul etkililiği (Atılkan, 2019; Cerit ve Yıldırım, 2017; Naml1, 2017), liderlik ve iş doyumu (Çek, 2011; Ereş ve Akyürek, 2016; Yılmaz ve Boğa Ceylan, 2011), liderlik ve örgütsel bağlılık (Buluç, 2009; Uğurlu ve Üstüner, 2011; Yaşbay, 2011), liderlik ve örgütsel vatandaşlık (Oğuz, 2011; Ünal ve Çelik, 2013) ve liderlik ve tükenmişlik (Bakan vd., 2015; Çetinkaya, 2017; Çulha, 2017) gibi birçok farklı değişken ile ilişkisini içeren araştırma yapılmıştır.

Liderlik geçmişten günümüze kadar yoğun bir şekilde incelenen bir kavram olma eğilimini kaybetmemiştir. Bu durumun en önemli sebeplerinden biri liderlerin sahip oldukları formal ve informal yetkiler ile gerek çalışanların performansı gerekse kurumların etkinliğini değiştirme ve geliştirme kabiliyetleridir. Nitekim Şişman (2018) okul müdürlerinin sergiledikleri liderlik davranışları ile okul çıktıları üzerinde doğrudan bir etkiye sahip olduğunu belirtmiştir. Bu 
bağlamda liderlik; okullar, okulların geliştirilmesi ve onların etkili birer okul özelliği taşımalarında önemli bir faktör olarak güncelliğini korumaktadır.

Özetle liderlik ve okul etkililiği arasındaki ilişkiyi içeren çalışmaların toplam etkisinin metaanaliz yöntemi ile ortaya koymaya çalışacak olan mevcut araştırma, "Liderlik ve okul etkililiği arasındaki ilişkinin birleştirilmiş etki büyüklüğü düzeyi nedir?" sorusu ile "Liderlik ve okul etkililiği arasındaki ilişkileri ortaya koyan çalışmaların etki büyüklükleri arasındaki çeşitli moderatör değişkenler açısından istatistiksel olarak anlamlı bir farklılaşma var mıdır?" sorularına cevap aramaktadır.

\section{YÖNTEM}

$\mathrm{Bu}$ araştırmada model olarak sistematik derleme ve sentezleme metotlarından olan meta-analiz yöntemi kullanılmıştır. Sistematik derleme, belirli bir araştırma sorusunu cevaplayabilmek için, igili araştırma sorusu kapsamında yapılmış çalışmaların belirli ölçütler dâhilinde bir araya getirilerek sentezlenmesidir (Higgins ve Green, 2011). Sistematik derlemelere dâhil edilecek çalışmalar amacına göre nitel ve nicel olarak ayrı ayrı ele alınabilir. Nicel çalışmaların incelenmesi için kullanılan meta-analiz, aynı konuda yapılmış benzer veriler içeren farklı çalışmalara ilişkin verilerin tek bir çalışma altında sentezlenerek genel bir sonuç elde edilmesini ve ilgili çalışmaların sonuçlarının istatistiksel olarak birleştirilmesini ifade etmektedir (Borenstein vd., 2013). Bu araştırmanın amacı, liderlik ile okul etkililiği arasındaki ilişkinin etki düzeyinin meta-analiz yöntemi ile incelenmesidir. Analiz işlemlerine başlamadan önce gerçekleştirilecek işlemler ile analiz adımlarında dikkat edilecek hususlar ve meta-analiz işlem adımları şu başlıklar altında yapılandırılmıştır: (i) ilgili çalışmaların seçimi, (ii) analiz için gereken verilerin hazırlanması, (iii) modele karar verilmesi, (iv) sonuçların yorumlanması.

\section{1. Çalışmaların Seçimi}

Ölçütlerin belirlenmesi en önemli husustur. Çünkü hangi çalışmaların veri havuzuna alınacağ bu ölçütler sayesinde belirlenecektir (Dinçer, 2021). Ayrıca, Berman ve Parker (2002) çalışmaların belirlenmesi için öngörülen ölçütlerin, amaca uygun olması ve açıça belirtilmesinin yayın yanlılığının önüne geçebilmek için de önemli olduğunu ifade etmiştir. Bu araştırmaya dâhil edilecek çalışmaların belirlenmesinde şu ölçütler dikkate alınmıştır:

\section{Veri tabanlar}

Meta-analiz çalışmalarında iki farklı görüş yer almaktadır: bunlardan ilki tüm çalışmların metaanalize dâhil edilmesi ikincisi ise çalışma seçiminde kalite faktörüne önem verilmesidir. Bu bağlamda tezler ve hakemler tarafından değerlendirmesi yapılmış makalelerin asgari yeterlilikleri sağladığı söylenebilir. Bu bağlamda çalışmamız ilgili konu bağlamında yapılan makale ve tezleri içermektedir. Farklı bakış açılarının farkında olunarak diğer yayınlar (bildiri, rapor vb.) kapsam dışında tutulmuştur fakat yine de bu bir sınırlılık olarak düşünülebilir. Araştırmanın amacı doğrultusunda liderlik ve okul etkililiği düzeyleri arasındaki ilişkiyi içeren araştırma havuzuna eklenecek tez ve makalelerin belirlenmesinde Yükseköğretim Kurulu Ulusal Tez Merkezi, Web of Science (WOS), Education Resources Information Center (ERIC), Scopus, EBSCOhost, TÜBİTAK ULAKBİM Sosyal ve Beşerî Bilimler Veri Tabanı, Dergipark ve Google Akademik veri tabanlarından faydalanılmıştır. Liderler, içinde bulundukları kültürel çevrenin özellikleri çerçevesinde hareket etmektedirler. Bu durum ise liderlik stili, yönetim tarzı, liderin 
davranış ve özellikleri gibi birçok alanda farklılaşmalara sebep olmaktadır (Yeşil, 2013). Bu nedenle araştırmacılar tarafından tez ve makalelerin örneklem grubunun Türkiye ile sınırlandırılması, makalelerin hakemli dergilerde yayınlanmış olan makaleler olması ve çalışmaların tez ve makalelerden oluşması kararlaştırılmıştır. Araştırma havuzu oluşturulurken araştırmaya konu olan çalışmalar veri tabanlarından, "Liderlik", "leadership", "etkili okul", "okul etkililiği", "effective school", "school effectiveness" anahtar kelimeleri kullanılarak, başlık ve özet bilgiler esas alınarak filtreleme yolu ile elde edilmiştir.

\section{İstatistikî Verilere Ulaşılabilirlik}

Meta-analiz araştırmalarında etki büyüklüklerinin belirlenebilmesi için değişkenler arasındaki ilişkiyi ortaya koyan korelasyon katsayısı ve örneklem büyüklükleri dikkate alınmıştır. Ayrıca etki büyüklügüne ulaşılmasına imkân veren korelasyon katsayısı ile standart hata; regresyon analizine dayalı işlemlerden çıkarılabilecek ilişki katsayıları gibi etki büyüklüklerinin hesaplanmasına imkân veren diğer değerlerde kullanılmıştır. Ancak değişkenlerin sadece alt boyutlarına ilişkin korelasyon katsayılarını ve genel korelasyon katsayısı hesaplanamayan çalışmalar araştırma kapsamına alınmamıştır. Bu sebeple, araştırmanın örneklemini Türkiye'de 2010-2020 yılları arasında gerçekleştirilen ve erişime açık olan toplam 21 (14 tez - 7 makale) akademik yayın içermektedir. Ancak Özkan'ın (2014) araştırmasında iki farklı örneklem (yönetici/öğretmen) kullanılmış ve her grup için ayrı sonuçlar elde edilmiştir. Özkan'ın (2014) araştırması ayrı çalışmalar olarak ele alınmıştır. Bu bağlamda meta-analiz kapsamında kullanılacak istatistiksel bilgiler içeren bireysel çalışma sayısı 22 olarak belirlenmiştir.

\section{Verilerin Analize Hazırlanması}

Araştırmanın analiz aşamasına başlamadan önce ilk olarak kodlama formunun hazırlanması, bireysel çalışmaların etki büyüklügü belirlenerek birleştirilmiş etki büyüklüğü üzerinde anlamlı etki gösteren, yayın yanlılığı oluşturan ve meta-analiz kapsamına dâhil edilip edilmeyeceğine ilişkin işlemler verilerin analize hazırlanması sürecinde gerçekleştirilmiştir.

\section{Kodlama formunun oluşturulması}

Meta-analizde araştırma raporlarının kodlanması çalışmanın en önemli aşamalarındandır. Kodlama işlemi Microsoft Office Excel programı aracılığıyla yapılmıştır. Programda öncelikle bir kodlama formu oluşturulmuştur. Verilerin toplanmasından sonra araştırmaya dâhil edilen bireysel çalışmalara ait bilgiler daha önce yazarlar tarafından hazırlanan kodlama formu kullanılarak kodlanmıştır. Bu form üç ana bölüm şeklinde hazırlanmıştır: Çalışma kimliği, çalışma içeriği, çalışma verileri. Çalışmanın kimliği başlı̆̆ı altında çalışmanın yazar(lar)ına, yayım yılına, türüne (tez, makale) dair bilgiler bulunmaktadır. Çalışma içeriği başlığı altında araştırmanın gerçekleştiği bölge, okul kademesi ve araştırmada tercih edilen ölçeklere (ölçek sahibi, geliştiren) dair bilgiler kodlanmıştır. Çalışma verileri başlığı altında ise birleştirilmiş etki büyüklügünün bulunabilmesi için bireysel çalışmalara ait örneklem büyüklüğü ve korelasyon katsayısı (ya da ilişki katsayısına ulaşmaya imkân veren diğer veriler) bilgileri kodlanmıştır.

Kodlamanın güvenilirliğini sağlamak için iki araştırmacı tüm verileri ayrı ayrı kodlamıştır. Kodlayıcılar arasındaki uyum Microsoft Office Excel programı ile kontrol edilmiş, tespit edilen farklılıklar üzerinde tartışmalar yürütülerek nihai kararlar verilmiştir. Toplanan bilgiler ve alan yazın incelemesi sonucunda çalışmaya ait moderatör değişkenler aşağıdaki şekilde belirlenmiştir: 

a) Yayin türü
b) Yapıldığı (örneklem) bölgesi
c) Okul türü
d) Liderlik türü
e) Ölçek (okul etkililiğ̈i) türü

\section{Çalışmaların etki büyüklüklerinin hesaplanması}

Standartlaştırılmış ortalama farkı, korelâsyon ve olasılık oranına dayalı olarak hesaplanabilen etki büyüklüğü (Şen ve Yıldırım, 2020), iki değişken arasındaki ilşkiyi nicel olarak ölçmek için kullanılabilir (Borenstein vd., 2013). İlişkisel tarama modelleri için meta-analizde kullanılan etki büyüklüğü indeksi Pearson çarpım-moment korelsyon katsayısı ve türevleridir. Bu meta-analiz çalışması, ilişkisel tarama modellerini içeren çalışmaları kapsamakta ve analiz kapsamına alınan her çalışmanın etki büyüklüğü değeri, birleştirilmiş (genel) etki büyüklüğü ve yayın yanlılığına dair analiz sonuçları Comprehensive Meta-Analysis (CMA) İstatistiksel Paket programı kullanılarak hesaplanmıştır.

\section{Çalışmaların yayın yanlı̆̆ııın incelenmesi}

Bir meta-analiz çalışması yapılırken sonucu etkileyebilecek en önemli etmenlerden biri yayın yanlılığıdır. Veri tabanlarının eksik ya da yetersiz bir biçimde taranması ve sadece anlamlı çalışmaların araştırma havuzuna dâhil edilmesi yayın yanlılığına sebep olabilmektedir (Dinçer, 2021). Ayrıca yayımlanmış çalışmalara ulaşılabilme ihtimali daha yüksek olduğundan, bu çalışmaların araştırma havuzuna dâhil edilmesi daha olası bir durumdur, çalışmalar çoğunlukla istatistiksel olarak anlamlı olduğu için bu durum muhtemel bir yanlılığa neden olacaktır (Rosenthal, 1979). Bu tür sebeplerle çalışmada bir yayın yanlılığının var olup olmadığı incelenmelidir. Mevcut araştırmanın yayın yanlılığı gösterip göstermediğini belirlemek için huni saçılım grafiği, Rosenthal'in güvenli n testi, Begg ve Mazumdar sıra korelasyonları, Egger'in doğrusal regresyon yöntemi kullanılmıştır. Huni saçılım grafiği incelenirken araştırma havuzuna alınan çalışmaların bireysel etki büyüklüklerinin grafikteki dağılımı önemlidir. Etki büyüklüklerinin, huni çizgilerinin içinde ve ortada yer alan çizgiye göre simetrik bir şekilde dağılması yayın yanlılığının var olmadığı; huni çizgilerinin dışında ve ortada yer alan çizgiye göre asimetrik bir dağılım sergiliyor ise de yayın yanlılığına işaret ettiği şeklinde yorumlanabilir (Dinçer, 2014; Şen ve Yıldırım, 2020). Meta-analize dâhil edilen çalışmaların etki büyüklüklerine ait Funnelplot grafik (Huni saçlım grafiği) Şekil 1'de verilmiştir. 


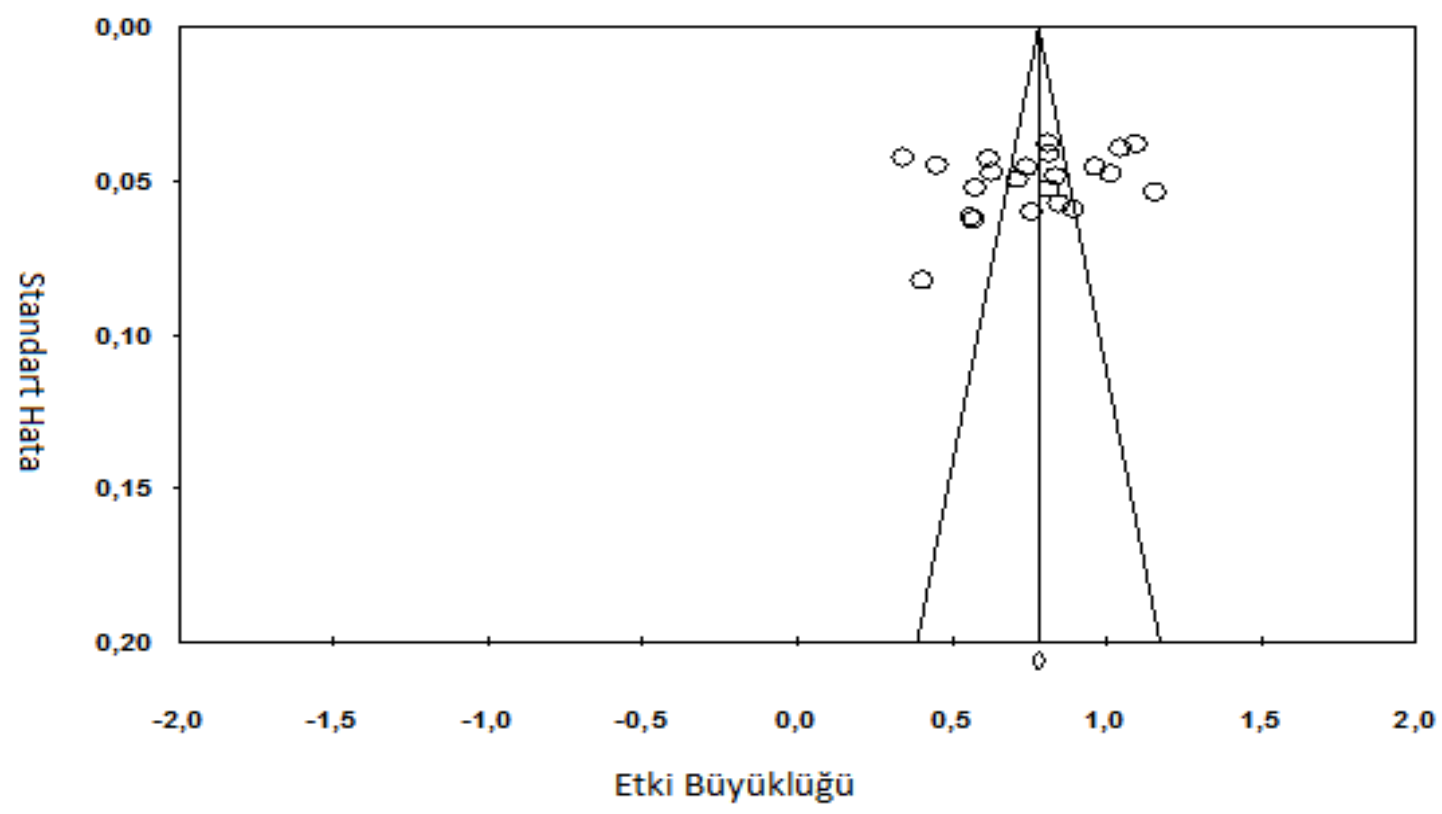

Şekil 1. Huni saçılım grafiğ i

Grafik 1 incelendiğinde meta-analize dâhil edilen bireysel çalışmalara ait etki büyüklüklerinin genel olarak huni içerisinde ve simetrik bir şekilde dağıldığg söylenebilir. Yayınların huni grafiğinin ortasında yer alan dikey çizginin her iki tarafında simetrik bir s,ekilde konumlanması yayın yanlılığının olmadığı şeklinde yorumlanmaktadır (Borenstein vd., 2013). Huni saçılım grafiğine göre meta-analize dâhil edilen 22 çalışmanın yayın yanlılı̆̆ı göstermediği söylenebilir. Ancak huni saçılım grafiği değerlendirilirken öznel bakış açıları yorumlamayı etkileyebilmektedir. Bu nedenle yayın yanlılığını belirlemek için geliştirilen diğer yanlılık istatistiklerinin incelenmesi önerilmektedir. Meta-analize kapsamına alınan araştırmaların yanlılığa ilişkin analiz verilerini içeren güven testleri ve sonuçları Tablo 1'de verilmiştir.

Tablo 1. Meta-analize kapsamına alınan çalışmaların yanlılık durumunu gösteren güven testleri ve sonuçları

\begin{tabular}{llr}
\hline Güven Testleri & Güven Testi Verileri & \\
\hline & İncelenen çalışmalar için Z-değeri & 73.825 \\
& İncelenen çalışmalar için $p$-değeri & .000 \\
Rosenthal'in Güvenli N Testi & Alfa & .050 \\
& Yön & 2 \\
& Alfa için Z değeri & 1.956 \\
& İncelenen çalışma sayısı & 22 \\
& Güvenli N (FSN) & 1192 \\
\hline & Tau & -0.138 \\
Begg - Mazumdar S. Korelasyonu & Tau için z değeri & 0.902 \\
& $p$ değeri (1 kuyruklu) & 0.184 \\
& $p$ değeri (2 kuyruklu) & 0.366 \\
\hline
\end{tabular}




\begin{tabular}{llr}
\hline & Standart Hata & 5.667 \\
& $\% 95$ alt limit $(1$ kuyruklu) & 18.464 \\
& $\% 95$ üst limit $(2$ kuyruklu $)$ & 5.181 \\
Egger'in Doğrusal Regresyonu & $t$ değeri & 1.171 \\
& $s d$ & 20 \\
& $p$ değeri (1 kuyruklu) & .127 \\
& $p$ değeri (2 kuyruklu) & .255 \\
\hline
\end{tabular}

Tablo 1'e bakıldığında Rosenthal'in güvenli $n$ testi sonuçları incelendiğinde yapılan meta-analiz sonuçlarının istatistiksel olarak anlamlı olduğu $(p=.000)$ söylenebilir. Meta-analiz çalışmasında "Güvenli N Sayısı" anlamlı bulunan popülasyon etki büyüklüğü değerini istatistiksel olarak anlamsız hale getirebilmek için analize dahil edilmesi gereken çalışma sayısının ortaya koymaktadır (Dinçer, 2021; Şen ve Yıldırım, 2020). Meta-analiz sonucunun istatistiksel olarak anlamsız hale gelebilmesi yani $p>.05$ olabilmesi için etki büyüklügü değeri sıfır olan 1192 çalışma daha gerekmektedir. Ayrıca Begg ve Mazumdar sıra korelasyon analizi incelendiğinde Kendall'ın Tau katsayısının istatistiksel olarak anlamlı olmaması $(-.138$ ve $p=.366)$ yayın yanlılığının olmadığına işaret etmektedir. Yine Egger'in doğrusal regresyon yöntemi ile ortaya konan analiz sonucu $(p=.255>.05) \% 95$ güvenle veri setinde yayın yanlılı̆̆ının var olmadığı söylenebilir.

\section{Analiz Modeline Karar Verilmesi}

Bir meta-analiz çalışmasında sabit etkiler modeli mi rastgele etkiler modeli mi kullanılacağ belirtilmelidir. Bunun için çeşitli analizler yapılarak etki büyüklüklerinin homojenliği test edilerek kullanılacak model belirlenebilir. Fakat Başol (2016) model seçimine analizler öncesinde karar verilmesi gerektiğini ifade etmiş ve güncel literatürde model belirlemek için yalnızca $Q$ testinin kullanılmaması gerektiğinin altını çizmiştir. Ayrıca sosyal bilimler alanında yapılan çalışmalarda, etki büyüklüğü analizi için rastgele etki modelinin kullanımı tavsiye edilmektedir (Field ve Gillett, 2010). Mevcut araştırmamıza ait çalışma konu alanının sosyal bilimler içerikli olması, çalışmaların yapıldığı eğitim kademeleri, tercih edilen desen ve ölçek gibi araştımaya ait değişkenlerin çeşitlilik göstermesinden dolayı meta-analiz için rastgele etkiler modelinin tercih edilmesinin daha uygun olduğuna karar verilmiştir. Ancak araştırmanın ilerleyen aşamalarında alt grup analizlerde heterojenlik düzeyinin ve kaynağının belirlenebilmesi için $Q$ testi yapılacağı için ilgili veri setine Homojenlik Testi de uygulanmıştır.

Çalışmaya dâhil edilen araştırmaların homojenlik testi sonucunda elde edilen $Q$ değeri istatistiksel olarak anlamdır $[Q=457.347, p=.000] \cdot \chi 2$ tablosunda 21 serbestlik derecesi için $\% 95$ anlamlılık düzeyinde eşik değeri 32.67 olarak bulunmuştur. $Q$ istatistik değeri $(Q=457.347) \chi 2$ dağılımının eşik değerinden 21 serbestlik derecesi ile $[\chi 2(.95)=32.67]$ daha yüksek bulunması ve $\mathrm{p}$ değerinin $(p=.000) .05$ 'ten küçük olması etki büyüklükleri dağılımının heterojen olduğunu göstermeketedir. $\mathrm{Q}$ istatistiğini tamamlayıcı olarak, çalışmalar arasındaki heterojenlik miktarı $\mathrm{I}^{2}$ (I-kare) istatistiği ile de ölçülmüştür. I² (I-kare) çalışmalar arası varyansın şanstan değil heterojenlilten kaynaklandığını gösteren yüzdelik bir değerdir (Şen ve Yıldırım, 2020). Heterojenlik miktarını gösteren test sonucunda I² değeri \%95.408 olarak bulunmuştur. Bu değer yorumlanacak olursa çalışmalar arasındaki toplam değişkenliğin yüzdesi (\%95.408) olarak ifade edilebilir. $I^{2}$ değerinin \%75'in üzerinde olmasının yüksek heterojenliği gösterdiği belirtilmiştir 
(Borenstein vd., 2013: 119). Bu bağlamada ölçülen $I^{2}$ değerinin \%95.408 $\left(I^{2}=95.408\right)$ yüksek düzeyde heterojenliğin bir göstergesi olduğu ifade edilebilir. Ölçülen $Q$ ve $I^{2}$ değerleri çalışmalara ait etki büyüklüklerinin heterojen bir dağılıma sahip olduğunu gösterdiği için mevcut araştırma için rastgele etkiler modelinin tercih edilmesini analiz sonuçları ile de desteklendiğini söyleyebiliriz.

\section{Sonuçların Yorumlanması}

İlişkisel araştırmalarda sunulan korelasyon katsayısı, etki büyüklügü olarak kullanılabilir. Fakat meta-analiz çalışmalarında varyansın korelasyona oldukça bağlı olması nedeniyle korelasyon katsayı değerleri "Fisher Z" ölçeğine dönüştürülerek işlemler yapılmaktadır. Genel etki ve güven aralığı gibi bulgular değerlendirilirken ise, raporlama için tekrar korelasyon katsayısına dönüştürülerek yorum yapılmalıdır (Borenstein vd., 2013; Önder ve Tulunay Ateş, 2017). Cohen ve arkadaşları (2007: 521) etki büyüklüğü olarak kullanılacak korelasyon katsayılarının aşağıdaki değer aralıklarında yorumlanabileceğini belirtmişlerdir:

Tablo 2. Etki büyüklükleri sınıflandırması

\begin{tabular}{cc}
$<0+/-0.1$ & Çok zayıf \\
$<0+/-0.3$ & Zayıf \\
$<0+/-0.5$ & Orta derece \\
$<0+/-0.8$ & Güçlü \\
$\geq+/-0.8$ & Çok güçlü \\
\hline
\end{tabular}

\section{BULGULAR}

Çalışmanın bu bölümünde, liderlik ve okul etkililiği arasındaki ilişki düzeyini belirlemeye yönelik yapılan analizlere yer verilmiştir. Öncelikle araştırma havuzuna dâhil edilen çalışmaların betimleyici istatistiklerine ait bulgular sunulmuştur. Akabinde liderlik ve okul etkililiği arasındaki ilişki düzeyini konu alan araştırmaların meta-analiz sonucu ortaya konan etki analizlerinin sonuçları sunulmuştur. İlaveten çalışmalardan toplanan alt grup verilerden yararlanılarak hesaplanan etki büyüklüğü değerleri okul etkililiği bağlamında incelenerek bu değişkenlere ait alt grup (moderatör) analizleri yapılmış ve bunların sonuçları da raporlanmıştır.

Araştırma kapsamında, araştırma havuzuna alınan çalışmaların alt grup değişkenlere ilişkin betimleyici istatistikler çalışmalardan çekilerek kodlanmıştır. Bu doğrultu, araştırma havuzuna alınan çalışmaların alt grup (moderatör) değişkenlere göre (çalışmanın yayın türüne, örneklem bölgesine, uygulandığı okul kademesine, liderlik türü ve çalışmada tercih edilen ölçeklerin [okul etkililği] türüne) frekansı ve yüzdeleri Tablo 3'te sunulmuştur. 
Tablo 3. Moderatör değişkenlerine ait betimsel istatistikler

\begin{tabular}{|c|c|c|c|}
\hline Moderatör Değişken & & $f$ & $\%$ \\
\hline \multirow{2}{*}{ Yayım Türü } & Makale & 7 & 31,82 \\
\hline & Tez & 15 & 68,18 \\
\hline \multirow{7}{*}{ BÖLGE } & Akdeniz Bölgesi & 2 & 9,09 \\
\hline & Doğu Anadolu Bölgesi & 3 & 13,64 \\
\hline & Ege Bölgesi & 3 & 13,64 \\
\hline & İç Anadolu Bölgesi & 6 & 27,27 \\
\hline & Marmara Bölgesi & 4 & 18,18 \\
\hline & Karadeniz Bölgesi & 2 & 9,09 \\
\hline & Belirtilmemiş & 2 & 9,09 \\
\hline \multirow{9}{*}{ Okul Türü } & Okul öncesi & 1 & 4,04 \\
\hline & İlkokul & 2 & 9,09 \\
\hline & Ortaokul & 4 & 18,18 \\
\hline & Lise & 2 & 9,09 \\
\hline & İlkokul + Ortaokul & 4 & 18,18 \\
\hline & İlkokul + Ortaokul + Lise & 6 & 27,27 \\
\hline & Okul Öncesi + İlkokul + Ortaokul + Lise & 1 & 4,04 \\
\hline & Bilsem & 1 & 4,04 \\
\hline & Belirtilmemiş & 1 & 4,04 \\
\hline \multirow{4}{*}{ Liderlik Türü } & Dönüşümcü Liderlik & 2 & 9,09 \\
\hline & Liderlik Stilleri & 5 & 22,73 \\
\hline & Öğretimsel Liderlik & 3 & 13,64 \\
\hline & Diğer & 12 & 54,55 \\
\hline \multirow{6}{*}{ Okul Etkililiği Ölçeği } & Hoy ve Ferguson, 1985 & 7 & 31,82 \\
\hline & Balc1, 2002 & 5 & 22,73 \\
\hline & Şişman, 1996 & 4 & 18,18 \\
\hline & Uğurlu ve Abdurrezzak, 2015 & 2 & 9,09 \\
\hline & Çobanoğlu, 2008 & 2 & 9,09 \\
\hline & Diğer (Ayık, 2007; Witmer, 2005) & 2 & 9,09 \\
\hline
\end{tabular}

Tablo 3 incelendiğinde araştırma havuzuna dâhil edilen çalışmaların \%31,82'si $(f=7)$ makalelerden, \%68.18'i $(f=15)$ tezlerden oluşmaktadır. Çalışmaların çoğunluğu \%27.27'si $(f=6)$ İç Anadolu Bölgesinde yapılmıştır. Çalışmaların çoğunluğu \%27.27'si $(f=6)$ ilkokul, ortaokul ve liseyi kapsayan karma bir örneklem üzerinde yürütülmüştür. Çalışmaların çoğunlukla liderlik stilleri bağlamında yapıldığ $\% 22.73$ 'ünü $(f=5)$ görülmektedir. Çalışmalarda okul etkililiği için tercih edilen ölçme aracının en çok \%31.82'sini $(f=7)$ Hoy ve Ferguson (1991) tarafından geliştirilen ölçeğin oluşturduğunu söyleyebiliriz. 
Araştırmada, “Liderlik ve okul etkililiği düzeyleri arasındaki ilişkinin birleştirilmiş (genel) etki büyüklügü nedir?" sorusu birinci alt problem olarak belirlenmiştir. Bu bağlamda meta-analiz için araştırma havuzuna dâhil edilen her çalışmanın ağırlığı, etki büyüklüğü ve genel etki büyüklüğü Tablo 4'te sunulmuştur.

Tablo 4. Etki büyüklüklükleri, genel etki büyüklü̆̆̈̈ (Fisher Z) ve ağırlıkları

\begin{tabular}{lccccccc}
\hline Çalışma & $\begin{array}{c}\text { Etki } \\
\text { Büyüklüğ̈̈ }\end{array}$ & $\begin{array}{c}\text { Standart } \\
\text { Hata }\end{array}$ & Alt Sınır & Üst Sınır & $Z$ & $p$ & $\begin{array}{c}\text { Ağırlık } \\
\text { (Rastgele } \\
\text { Etkiler) }\end{array}$ \\
\hline Ermeydan (2019) & 0,453 & 0,045 & 0,364 & 0,541 & 10,0 & .000 & 4,60 \\
Namlı (2017) & 0,343 & 0,042 & 0,260 & 0,426 & 8,1 & .000 & 4,62 \\
Zembat vd. (2010) & 0,563 & 0,062 & 0,442 & 0,684 & 9,1 & .000 & 4,44 \\
Baştoklu (2015) & 1,157 & 0,054 & 1,052 & 1,262 & 21,5 & .000 & 4,52 \\
Bildirici (2020) & 1,045 & 0,039 & 0,968 & 1,123 & 26,5 & .000 & 4,64 \\
Güngör (2018) & 0,811 & 0,038 & 0,737 & 0,885 & 21,4 & .000 & 4,66 \\
Abdurrezzak (2015) & 0,837 & 0,049 & 0,741 & 0,932 & 17,2 & .000 & 4,57 \\
Tuncel (2013) & 1,096 & 0,038 & 1,021 & 1,170 & 28,8 & .000 & 4,65 \\
Yılmaz (2010) & 0,964 & 0,046 & 0,875 & 1,053 & 21,2 & .000 & 4,60 \\
Atılkan (2019) & 0,758 & 0,060 & 0,640 & 0,876 & 12,6 & .000 & 4,46 \\
Delice (2020) & 0,576 & 0,052 & 0,474 & 0,679 & 11,0 & .000 & 4,54 \\
Kılıç (2017) & 0,814 & 0,053 & 0,711 & 0,918 & 15,5 & .000 & 4,53 \\
Özkan (2014a) & 0,628 & 0,047 & 0,536 & 0,721 & 13,3 & .000 & 4,58 \\
Özkan (2014b) & 0,406 & 0,082 & 0,244 & 0,568 & 4,9 & .000 & 4,20 \\
Cerit vd. (2017) & 0,571 & 0,063 & 0,448 & 0,694 & 9,1 & .000 & 4,43 \\
Yörük vd. (2012) & 0,893 & 0,059 & 0,777 & 1,009 & 15,1 & .000 & 4,47 \\
Cansoy vd. (2018) & 0,618 & 0,043 & 0,534 & 0,702 & 14,4 & .000 & 4,62 \\
Nartgün vd. (2020) & 0,712 & 0,050 & 0,615 & 0,809 & 14,4 & .000 & 4,56 \\
Eren (2020) & 1,013 & 0,048 & 0,919 & 1,107 & 21,2 & .000 & 4,58 \\
Yumlu (2020) & 0,814 & 0,041 & 0,734 & 0,895 & 19,8 & .000 & 4,63 \\
Işik (2020) & 0,848 & 0,057 & 0,735 & 0,961 & 14,8 & .000 & 4,49 \\
Koçak vd. (2020) & 0,741 & 0,046 & 0,652 & 0,831 & 16,2 & .000 & 4,60 \\
Sabit Etkiler & 0,779 & 0,010 & 0,759 & 0,799 & 75,9 & .000 & \\
\hline Rastgele Etkiler & 0,759 & 0,048 & 0,665 & 0,853 & 15,8 & .000 & \\
\hline
\end{tabular}

Tablo 4 incelendiğinde, liderlik ve okul etkililiği arasındaki ilişkinin genel etki büyüklüğü sonucu (Fisher $z$ cinsinden) rastgele etki modeline göre .759 olarak bulunurken belirlenen değer Pearson korelasyon ( $r$ ) değerine dönüştürüldüğünde .64 olarak bulunmuştur. Cohen vd., (2007) korelasyon etki düzeyi tablosuna göre güçlü bir etki olduğu söylenenbilir. Güven aralığı rastgele etkiler modeli açsından incelendiğinde $\% 95$ güven aralığı düzeyinde etki büyüklügüünün alt sınırı .665 ve üst sınırı ise .853 olarak bulunmuştur. Etki büyüklüklerine ilişkin değerler rastgele etki modeline göre istatistiksel olarak anlamlıdır $(Z=15.8, p=.000)$. Bu bulgular ışığında liderlik ve okul etkililiği ilişki düzeyleri arasında pozitif yönlü ve güçlü bir ilişkinin olduğu ifade edilebilir. Araştırma kapsamında, "Liderlik ve okul etkililiği düzeyleri arasındaki ilişkileri inceleyen araştırmaların alt grupları arasında (çalışmaların yayın türüne, örneklem bölgesi, okul kademesi ve çalışmalarda tercih edilen ölçeklerin [okul etkililiği] türü) etki büyüklükleri açısından istatistiksel 
olarak anlamlı bir farklılaşma var mıdır?" sorusu ikinci alt problem olarak belirlenmiştir. Bu nedenle, araştırma hauzuna alınan çalışmaların alt grup değişkenlere göre $Q$ istatistiğihomojenlik testi yapılarak ve analiz sonuçları her bir alt grup için tablo halinde verilmiştir. Çalışmaların yayın türüne (makale ve tez) ilişkin etki büyüklüklerine ilişin test sonuçları Tablo 5 'te sunulmuştur.

Tablo 5. Yayın türüne dair etki büyüklükleri ve homojenlik testi sonuçları

\begin{tabular}{lccccccc}
\hline Moderatör & \multicolumn{4}{c}{ \%95 Güven Aralı̆g̀ } & \multicolumn{3}{c}{ Homojenlik Testi } \\
Yayım Türü & $k$ & $E B / r$ & Alt sınır & Üst Sinır & $\mathbf{Q}_{\mathrm{B}}$ & sd & $\boldsymbol{p}$ \\
\hline Makale & 7 & $.707 / .609$ & .617 & .796 & .913 & 1 & .339 \\
Tez & 15 & $.783 / .654$ & .655 & .910 & & & \\
\hline
\end{tabular}

Çalışmalar yayın türü açısından hem makale ve tez olarak hem de yüksek lisans (tez), doktora (tez) ve makale olarak iki farklı şekilde kategorik hale getirilerek yayın türünün genel etki büyüklüğü üzerindeki etkisi belirlenmeye çalışılmıştır. Her iki sınıflama türü açısından anlamlı bir farklılık bulunamamıştır. Alan yazın incelendiğinde yayın türü açısından farklılıkları ortaya koymak için yapılan çalışmaların çoğunlukla tez ve makale şeklinde bir sınıflama ile yapıldığı görülmüştür. Mevcut çalışmada tez-makale şeklindeki sinıflamaya ait sonuçlar sunulmuştur. Yayın türünün genel etki büyüklüğü açısından anlamlı bir farklılık oluşturup oluşturmadığına bakıldığında, makale kategorisine ait etki büyüklüğü değerinin (.609) tez kategorisine ait etki büyüklüğü değerinden (.654) daha düşük olduğu belirlenmiştir. $Q_{B}$ istatistik değeri $\left[Q_{B}=.913, p\right.$ $=.339] \% 95$ anlamlılık düzeyinde ve serbestlik derecesi (1) ile hesaplanan $\chi 2$ dağılımının kritik değerinden $[\chi 2(.95)=3.841]$ daha düşük olması nedeniyle istatistiksel olarak anlamlı değildir. Yani, yapılan meta-analiz sonucuna göre araştırma havuzundaki çalışmaların yayın türüne dair etki büyüklüklerinden kaynaklanan istatistiksel olarak anlamlı bir farklılık yoktur.

Çalışmaların yürütüldüğü örneklem bölgelerine dair etki büyüklüklerinin dağıllımı ve homojenlik testi sonuçları Tablo 6'da sunulmuştur.

Tablo 6. Araştırmalarn yürütüldü̈̆̈̈ örneklem bölgelerine dair etki büyüklükleri ve homojenlik testi sonuçlar

\begin{tabular}{lccccccc}
\hline Moderatör & \multicolumn{4}{c}{ \%95 Güven Aralı̆̆ } & \multicolumn{3}{c}{ Homojenlik Testi } \\
Bölge & $\boldsymbol{k}$ & $\boldsymbol{E} \boldsymbol{B} / \boldsymbol{r}$ & Alt sınır & Üst Sınır & $\mathbf{Q}_{\mathrm{B}}$ & $\boldsymbol{s} \boldsymbol{d}$ & $\boldsymbol{p}$ \\
\hline Akdeniz Bölgesi & 2 & $.512 / .472$ & .390 & .633 & 18.558 & 5 & .002 \\
Doğu Anadolu Bölgesi & 3 & $.742 / .630$ & .315 & 1.168 & & & \\
Ege Bölgesi & 3 & $.808 / .668$ & .732 & .885 & & & \\
İç Anadolu Bölgesi & 6 & $.855 / .694$ & .655 & 1.055 & & & \\
Karadeniz Bölgesi & 2 & $.665 / .582$ & .482 & .849 & & & \\
Marmara Bölgesi & 4 & $.754 / .638$ & .563 & .945 & & & \\
\hline
\end{tabular}

Çalışmaların yürütüldüğü örneklem bölgelerinin birleştirilmiş etki büyüklüğü üzerindeki etkisini belirlemek için çalışmalar, yürütüldüğü ilin bulunduğu çoğrafi bölgeye göre sınıflandırılmıştır. Fakat iki çalışmada örneklem bölgesine ilişkin veri olmadığı için analize dâhil edilmemiştir. Çalışmaların yapıldığı bölgeye dair en büyük etki büyüklüğü değerinin (.694) İç Anadolu Bölgesi; en düşük etki büyüklüğü değerinin ise (.472) Akdeniz Bölgesi olduğu 
görülmektedir. $\mathrm{Q}_{B}$ istatistik değeri $\left[\mathrm{Q}_{\mathrm{B}}=18.558, p=.002\right] \% 95$ anlamlılık düzeyinde ve beş serbestlik derecesi ile $\chi 2$ dağılımı eşik değerinden $[\chi 2(.95)=11.0705]$ yüksek olması anlamlılığın bir göstergesidir. Bu sonuç, meta-analize alınan çalışmaların örneklem bölgelerine dair yapılan moderatör analizi sonucuna göre etki büyüklükleri arasında istatistiksel olarak anlamlı bir farklılık olduğu ifade edilebilir.

Çalışmaların yapıldığı okul türüne dair etki büyüklüklerinin dağılımı ve ait homojenlik testi sonuçları Tablo 7'de verilmiştir.

Tablo 7. Araştırmaların yapıldığı okul kademesine dair etki büyüklükleri ve homojenlik testi sonuçları

\begin{tabular}{lccccccc}
\hline Moderatör & \multicolumn{4}{c}{ \%95 Güven Aralı̆̆ } & \multicolumn{3}{c}{ Homojenlik Testi } \\
Bölge & $\boldsymbol{k}$ & $\boldsymbol{E} \boldsymbol{B} / \boldsymbol{r}$ & Alt sınır & Üst Sınır & $Q B$ & sd & $\boldsymbol{p}$ \\
\hline İlkokul & 2 & $.794 / .661$ & .361 & 1.227 & 12.098 & 4 & .017 \\
Ortaokul & 4 & $.961 / .745$ & .803 & 1.118 & & & \\
Lise & 2 & $.616 / .548$ & .077 & 1.156 & & & \\
İlkokul + Ortaokul & 4 & $.818 / .674$ & .523 & 1.114 & & & \\
İlkokul + Ortaokul + Lise & 7 & $.653 / .574$ & .570 & .737 & & & \\
\hline
\end{tabular}

Çalışmaların uygulandığı okul kademesinin birleştirilmiş etki büyüklüğü üzerindeki etkisini belirlemek için çalışmalar; ilkokul, ortaokul, lise, ilkokul ile ortaokul, ilkokul ile ortaokul ile lise şeklinde gruplandırılmıştır. Analizin yapılabilmesi için etki büyüklüğü belirlenirken kategorikleştirilen her grup için yeter sayıda çalışma gereklidir ve bu sayı minimum ikidir, ikiden az çalışmaya sahip olan okul türleri olan okul öncesi ve diğer kurumlar kategorisi ile okul kademesi belirtilmeyen (yazarlarından geri dönüt alınamayan) çalışmalar analizden çıkarılmıştır. Çalışma örnekleminin seçildiği okul kademesine dair en yüksek etki değerinin (.745) ortaokul; en düşük etki büyüklüğü değeri ise (.548) lise için bulunduğu söylenebilir. Sınıflar arası homojenlik testi değeri $Q_{B}=12.098$ olarak hesaplanmıştır. $Q_{B}$ istatistik değeri ise $\left[Q_{B}=12.098\right.$, $p=.017] \% 95$ anlamlılık düzeyinde ve serbestlik derecesi (4) ile $\chi 2$ dağılımının eşik değerinin $[\chi 2(.95)=9.487]$ üzerinde bulunması nedeni ile istatisiksel olarak anlamlıdır. Sonuç olarak, metaanalize dâhil edilen çalışmaların okul türüne dair yapılan alt grup analiz sonucuna göre etki büyüklükleri açısından istatistiksel olarak anlamlı bir farklılık olduğu söylenebilir.

Çalışmalarda araştırmaya konu edilen liderlik türüne ilişkin etki büyüklüklerinin dağılımı ve homojenlik testi sonuçları Tablo 8' de sunulmuştur.

Tablo 8. Liderlik türlerine dair etki büyüklükleri ve homojenlik testi sonuçları

\begin{tabular}{lccccccc}
\hline Moderatör & \multicolumn{3}{c}{ \%95 Güven Aralı̆̆ } & \multicolumn{3}{c}{ Homojenlik Testi } \\
Bölge & $k$ & $E B / r$ & Alt sınır & Üst sınır & $Q B$ & $s d$ & $p$ \\
\hline Dönüşümcü Liderlik & 4 & $.742 / .630$ & .486 & .998 & 21.241 & 3 & .000 \\
Liderlik Stilleri & 3 & $.609 / .543$ & .387 & .831 & & & \\
Öğretimsel Liderlik & 3 & $1.042 / .779$ & .932 & 1.151 & & & \\
Diğer & 12 & $.730 / .623$ & .615 & .844 & & & \\
\hline
\end{tabular}


Çalışmalara ait etki büyüklügü hesaplamaları yapılırken her grup için minimum iki çalışma gerektiğinden, araştırılan liderlik türlerinin bazılarında tek çalışma olması ve araştırma kapsamımızın liderlik olmasından hareketle tek olan çalışmaların "diğer türler" (Paternalist liderlik, kamu liderliği, destekleyici liderlik, etik liderlik vb.) başlığında toplanması kararlaştırılmıştır. Çalışmalarda araştırılan liderlik türüne ait en yüksek etki büyüklüğü değerinin (.779), öğretimsel liderlik; en düşük etki büyüklüğü ise (.623) diğer türler için hesaplandığ 1 görülmektedir. $Q_{B}$ istatistik değeri $\left[Q_{B}=21.241, p=.000\right] \% 95$ anlamlılık düzeyinde ve serbestlik derecesi (3) ile hesaplanan $\chi 2$ dağılımının eşik değerinin $[\chi 2(.95)=7.814]$ üzerinde bulunması nedeni ile istatistiksel olarak anlamlıdır. Bu bağlamda, meta-analize alınan çalışmaların liderlik türüne ilişkin yapılan alt grup analizi sonucuna göre etki büyüklükleri açısından istatistiksel olarak anlamlı bir farklılık olduğu ifade edilebilir.

Okul etkililiği düzeyini belirlemek için tercih edilen ölçme aracı türüne ilişkin etki büyüklüklerinin dağılımı ve homojenlik testi sonuçları Tablo 9'da verilmiştir.

Tablo 9. Çalışmalarda tercih edilen ölçme aracı (okul etkililiği) türüne dair etki büyüklükleri ve homojenlik testi sonuçları

\begin{tabular}{lccccccc}
\hline Moderatör & \multicolumn{4}{c}{$\% 95$ Güven Aralığı } & \multicolumn{3}{c}{ Homojenlik Testi } \\
Bölge & $k$ & $E B / r$ & Alt sınır & Üst sınır & $Q B$ & $s d$ & $p$ \\
\hline Hoy ve Ferguson, 1985 & 7 & $.640 / .565$ & .491 & .789 & 5.905 & 4 & .206 \\
Balcı, 2002 & 5 & $.856 / .694$ & .617 & 1.094 & & & \\
Şişman, 1996 & 4 & $.820 / .675$ & .633 & 1.007 & & & \\
Abdurrezzak, 2015 & 2 & $.707 / .609$ & .452 & .962 & & & \\
Çobanoğlu, 2008 & 2 & $.933 / .732$ & .706 & 1.159 & & & \\
\hline
\end{tabular}

Çalışmalarda tercih edilen okul etkililiği ölçeğinin birleştirilmiş etki büyüklüğü açısından bir farklılaşmaya sebep olup olmadığını belirlemek için tercih edilen ölçekler, araştırmacılara (ölçeği geliştiren) göre Hoy ve Ferguson (1985), Balcı (2002), Şişman (1996), Abdurrezzak (2015) ve Çobanoğlu (2008) olmak üzere beş gruba ayrılmıştır. Birleştirilmiş etki büyüklügüunün belirlenebilmesi için her grup için en az iki çalışma gerekmektedir. Bu nedenle analiz için yeter sayıda olmayan ölçek türleri analize dâhil edilmemiştir. Çalışmalarda kullanılan okul etkililiği ölçeği türüne ait en yüksek etki büyüklügü (.732) Çobanoğlu (2008) ve etki büyüklüğü değerinin en düşük olarak (.565) Hoy ve Ferguson (1985) tarafından geliştirilen ölçek için bulunduğu görülmektedir. $Q_{B}$ istatistik değeri $\left[Q_{B}=5.905, p=.206\right] \% 95$ anlamlılık düzeyinde ve serbestlik derecesi $(s d=4)$ ile hesaplanan $\chi 2$ dağılımının eşik değerinden $[\chi 2(.95)=9.487]$ düşük olması nedeniyle istatistiksel olarak anlamlı değildir. Bu bağlamda, meta-analize dâhil edilen çalışmaların ölçek türüne ilişkin yapılan moderatör analizine göre ölçekler arasında anlamlı bir farklılık bulunamamıştır.

\section{TARTIŞMA, SONUÇ VE ÖNERILLER}

Liderlik ve okul etkililiği arasındaki ilişki düzeyinin belirlenmesi amacıyla yapılan ve metaanaliz yönteminin kullanıldığı mevcut araştırmada dâhil etme ölçütlerine göre araştırma havuzuna alınan 22 çalışmanın ayrı ayrı etki büyüklükleri ile birleştirilmiş etki büyüklüğü hesaplanmıştır. Ayrıca liderlik ve okul etkililiği arasındaki ilişki düzeyini ortaya koymaya çalışan 
araştırmaların etki büyüklükleri arasında moderatör değişkenlere (çalışmanın yayın türüne, örneklem bölgesine, okul kademesine, liderlik türü ve çalışmada tercih edilen ölçeklerin [okul etkililği] türüne) göre anlamlı bir farklılık olup olmadığı ortaya konmuştur.

Araştırmanın güvenilir ve geçerli olduğunu ortaya koymak ve yayım yanlılı̆̆ını belirlemek amaciyla yapılan Begg ve Mazumdar sıra korelasyonu, Rosenthal'in güvenli $n$ testi, Egger'in doğrusal regresyon yöntemlerine göre yayın yanlılığı olmadığı söylenebilir. Meta-analize dâhil edilen çalışmaların birleştirilmiş etki büyüklüklerini hesaplamadan önce hangi meta-analiz modelinin kullanılması gerektiğine ilişkin kuramsal bakış açılarına ilaveten homojenlik testi de yapılmıştır. Alan yazın incelendiğinde, gerek meta-analiz için sosyal bilimler bağlamında yapılan görüşler, gerekse homojenliğin tespiti için yapılan testlerin sonucuna göre çalışmanın analiz modeli, rastgele etkiler modeli olarak kararlaştırılmış ve meta-analiz kapsamına alınan çalışmaların etki büyüklükleri rastgele etkiler modeli yöntemi kullanılarak birleştirilmiş ve etki büyüklüğü hesaplanmıştır.

Öncelikle araştırma havuzuna dâhil edilen çalışmaların betimleyici istatistiklerine bakıldığında, araştırma havuzuna dâhil edilen çalışmaların daha çok $(\% 68.18, f=15)$ tezlerden oluştuğu görülmüştür. Çalışmaların çoğunluğunda $(\% 27.27, f=6)$ örneklem bölgesi olarak İç Anadolu Bölgesininin seçildiği belirlenmiştir. Çalışmaların çoğunluğu $(\% 27.27, f=6)$ ilkokul, ortaokul ve liseyi kapsayan karma bir örneklem üzerinde yürütülmüştür. Çalışmaların çoğunun liderlik türü olarak "liderlik stilleri" alt başlığında yürütüldüğü $(\% 22.73, f=5)$ görülmektedir. Araştırmacıların çalışmalarda okul etkililiği için tercih ettikleri ölçme aracının en çok (\%31.82,

$f=7$ ) Hoy ve Ferguson (1985) tarafından geliştirilen ölçek olduğunu söyleyebiliriz. Sonucumuza paralel şekilde Turhan ve arkadaşları (2017) tarafından yapılan çalışmada okul etkililiği çalışmalarının daha çok tezlerden oluştuğu ve yine Polatcan ve Cansoy (2018) tarafından okul etkililiği bağlamında yapılan araştırmaya göre de araştırmacıların çoğunlukla Hoy ve Ferguson (1985) tarafından geliştirlen ölçeği kullandıkları belirtilmiştir.

Araştırmanın ilk bulgusu, liderlik ile okul etkililği arasında pozitif yönlü ve güçlü bir ilişkinin olduğu belirlenmiştir. Bu bulgu, Yirci ve Berk (2021) tarafından yürütülen nitel araştırma ile benzerlik göstermektedir, ilgili araştırmada katılımcılar etkili okulu oluşturan en önemli boyut olarak "yönetici" faktörünü belirtmişlerdir. Bu bulgu katılımcıların, araştırma deseninden bağımsız olarak yönetici ve okul etkililiğini yüksek düzeyde ilişkilendiren bir algıya sahip oldukları şeklinde yorumlanabilir. Bu bulgu aynı zamanda liderlik ve okul etkililiğinin araştırıldığı bireysel çalışma sonuçlarıyla da (Abdurrezzak, 2015; Atılkan, 2019; Işik, 2020; Tuncel, 2013; Yılmaz, 2010) uyumludur. Şişman (2018) eğitim yönetimi alanında gerçekleştirilen çalışmalar, liderin sergilediği davranışların okulun gelişim ve iyileştirilmesinde kritik bir öneme sahip olduğunu belirtmektedir. Hallinger ve Heck (1996) 1980-1995 yılları arasında yapılan ve etkili okulları inceleyen araştırmaları incelemiş ve okul liderlerinin öğretmen, öğrenci ve öğrenme üzerinde doğrudan ve dolaylı etkilere sahip oldukların ifade etmişlerdir. Bu bağlamda liderlik, okul etkililiği üzerinde önemli ve çok düzeyli etkilere sahip önemli bir kavram ve olgudur. Bu doğrultuda yöneticilerin liderlik becerilerinin geliştirilmesi doğrudan okulun gelişimini etkilerken dolaylı olarak okul ve okula ait çıtıları da etkileyecektir. Okula ait en önemli çıktı ise öğrenci yani toplumları oluşturan temel yapı taşı olan bireylerdir. O halde okul müdürü aldığı karar ve uygulamalar ile doğrudan okulu etkilerken, dolaylı olarak öğrenciyi ve tüm toplumu etkilemiş olacaktır. Bu bağlamda yöneticilerin liderlik becerileri üzerinde önemle durulmalı ve bu becerilerin gelişimi için politika yapıcılar ve karar merciindeki yetkililer tarafından gerekli stratejiler belirlenmelidir. 
Yayın türüne dair yapılan alt grup analiz sonuçlarına göre makale kategorisine ait etki büyüklüğü değerinin (.609) tez kategorisine ait etki büyüklüğü değerinden (.654) daha düşük olduğu bulunmuştur. Fakat bulunan bu sonuç istatistiksel olarak anlamlı değildir. Özdoğru ve Güçlü (2020) tarafından yapılan ve öğretimsel liderliğinin okul çıktıları üzerindeki etkisi inceleyen meta-analiz çalışmasına ait yayın türü değişkeni analiz sonucu araştırmamızın bulgusunu destekler niteliktedir. Ayrıca $p$ değerinin, örneklem büyüklüğünden etkilendiği bilinmektedir bu bağlamda mevcut çalışmada yayın türü açısından var olan örneklem farklılığının istatistiksel olarak anlamlılığı etkilemediği söylenebilir.

Örneklem bölgelerine dair yapılan analiz sonuçlarına göre yüksek etki büyüklügünün (.694) İç Anadolu Bölgesi; en düşük etki büyüklüğü değerinin ise (.472) Akdeniz Bölgesi olduğu bulunmuştur. Araştırmanın bu bulgusu istatistiksel olarak anlamlı bulunmuştur. Eğitim kurumu müdürlerinin liderliği ile öğretmen çıtılarının incelendiği bir meta-analiz çalışmasında sabit etkiler modeline göre farklılık bulunurken reastgele etkiler modeline göre bölgeler arası bir farklılık bulunamamıştır (Aydın ve Sarıer, 2013). Bu farklılık öncelikle, bölgeler arasındaki eğitim ve fırsat eşitliğinin eğitim araştırmaları üzerine bir yansıması olarak değerlendirilebilir. Bu bağlamda öğrenci çıktıları ve okulun sahip olduğu kaynaklar bölgesel farklılıklardan etkilenmektedir (Çelikdemir, 2020). Programme for International Student Assessment (PISA) 2015 'te okul yöneticilerinin eğitim liderliği becerileri incelenmiş ve kentsel bölgelerde çalışan okul yöneticilerinin eğitim liderliği endeksi puanının daha yüksek oduğu bulunmuştur (OECD, 2016). Bu doğrultuda, gerek okul imkânları gerekse eğitim liderliği becerilerinin kırsal ve kentsel olarak farklılaştığ1 söylenebilir. Bu bağlamda araştırma örneklem bölgelerinin çoğunlukla yapıldığı il düzeyinde ya da çoğrafi bölge düzeyinde belirtilmesi alt kırılımları (il, ilçe, köy) incelememize imkân vermemektedir. Ayrıca ölçme araçlarının geliştirilmesi ve kullanımı sırasında cinsiyet, bölge ve kültür gibi değişkenler açısından ölçme araçlarının incelenmediği yani ölçme araçlarının ölçüm değişmezliği açısından yeterli geçerlik kanıtlarına sahip olmadığ görülmektedir. Oysa birden fazla grup incelendiğinde her grup için sağlanması gereken ve ölçme aracının sahip olması gereken önemli özelliklerden biri olan yapı geçerliği kanıtlarından biri ölçme değişmezliğinin sağlanmasıdır (Başusta ve Gelbal, 2015). Oluşan bu farklılığın gelecekte yürütülecek çalışmalarda incelenmesi ve kullanılan ölçme araçlarına ait çok düzeyli geçerlik kanıtlarının sunulması araştırma sonuçlarını daha da net hâle getirecektir.

Çalışmaların uygulandığı okul kademesine göre en yüksek etki büyüklüğünün (.745) ortaokul; en düşük ise (.548) lise için hesaplandığı görülmüştür. Araştırmanın bu bulgusu istatistiksel olarak anlamlı bulunmuştur. Araştırma sonucumuzla benzer şekilde, Cemaloğlu (2009) liderlik stillerini farklı değişkenler açısından incelediği çalışmasında liderlik stilleri açısından öğretmenlerin algı düzeylerinin görev yaptıkları okul türüne göre farklılık gösterdiğini ifade etmiştir. Okul kademeleri öğrenci niteliği açısından farklılaşmakta bu durum ise çeşitli öğretmen çıktılarını etkiliyebilmektedir (Kalkan, 2020) ayrıca öğretmenlerin bulundukları kurumlara göre çalışma süreleri farklılaşmakta, dolayısıyla kurum ve lider ile olan etkileşim oranı değişmektedir. Örneğin ilkokul öğretmenleri haftanın tamamında okulda bulunurken, ortaokullarda öğretmenin okulda bulunma süresi, ders saatine göre değişmektedir. Böylece öğretmenin okulunu gözlemleme ve meslektaşları ile iletişim kurma süreci değişmektedir. Bu durum ise öğretmenlerin bulundukları eğitim kademesine göre bakış açılarını ve algılarını etkilemiş olabilir.

Çalışmalarda araştırılan liderlik türüne ait en yüksek etki büyüklüğü sonucunun (.779) öğretimsel liderlik; en düşük ise (.623) diğer türler için hesaplandığı görülmektedir. Araştırmanın 
bu bulgusu, liderlik türleri bağlamında yapılan moderatör analizi sonuçlarına göre istatistiksel olarak anlamlı bir farklılaşmanın olduğuna işaret etmektedir. Benzer şekilde Özdoğru ve Güçlü (2020) öğretimsel liderliğinin okul çıtıları üzerindeki etkisi inceleyen meta-analiz çalışmasında öğretimsel liderlik ve etkili okul değişkenlerinin güçlü bir ilişkiye sahip olduğunu belirtmiştir. Alan yazın incelendiğinde öğretimsel liderliğin okul ve okul çıtıları üzerinde anlamlı bir etkiye sahip olduğu sıklıkla belirtilmiştir (Özdemir ve Sezgin, 2002; Neufeld, vd., 1983; Hallinger ve Murphy, 1985). Bu bağlamda okul etkililiğinde öğretimsel liderliğin ön plana çıkması, okulun temel görevinin öğretim ve öğrenmenin gerçekleştirilmesi olarak düşünüldüğünde, okulun bu amaca ulaşmasında nihai sorumlu ve yetkilinin okul yöneticisi olduğu algısını oluşturmaktadır. $\mathrm{Bu}$ nedenle okul yöneticisinin diğer liderlik becerilerine göre daha baskın olarak program, öğrenme ve eğitim gibi öğretim süreç ve amaçlarında yetkin olduğu düşünülen öğretimsel liderlik kavramı ön plana çıkmaktadır.

Sonuç olarak liderlik ve okul etkililiği değişkenleri arasında güçlü ve pozitif yönlü bir ilişki olduğu ortaya konmuştur. Bu bağlamda okulların daha başarılı çıtılar sunmasında okul yöneticisinin liderlik özellikleri büyük bir önem taşımaktadır. Bu doğrultuda politika yapıcıların okullar için yapılacak idari düzenlemelerde yönetici seçimi ve yetiştirme uygulamaları üzerinde önemle durması tavsiye edilebilir. Ayrıca araştırmamız kapsamında ortaya konan moderatör değişkenler (çalışmanın yapıldığı bölge, okul kademesi ve liderlik türleri) açısından anlamlı bir farklılaşmanın olduğuna işaret etmektedir. Bu bağlamda okullar söz konusu olduğunda liderlik türlerinden öğretimsel liderlilik üzerinde ayrıca durularak, okul yöneticilerinin öğretim süreç ve amaçları konusunda gelişimlerinin desteklenmesi okulların etkililik düzeyini artıracaktır. Bölgeler arası farklılığın nedenleri, kullanılan ölçme araçlarından, OECD raporlarında da belirtilen kır-kent ayrımından ya da araştırmalarda tercih edilen liderlik türlerinden kaynaklanıyor olabilir. Bu nedenle araştırmamızın bir sınırlılığı olarak kabul edebileceğimiz kırkent ayrımı ve liderlik türlerini ayrı ayrı ele alabileceğimiz yeterli verinin olmaması bu moderatör değişkenlerde var olan farklılı̆̆ın sebeplerini ortaya koymamızı kısıtlamıştır. Bu doğrultuda bireysel araştırmacıların örneklem bölgelerini daha ayrıntılı belirtmelerinin ilerde yapılabilecek meta-analiz çalışmalarına katkı sağlayabileceğini düşünmekteyiz. Ayrıca okul kademeleri arasındaki farklılaşmanın bireysel araştırmalarda da ortaya çıktığı görülmektedir. $\mathrm{Bu}$ farklılaşmanın nedenlerinin daha detaylı ve derinlemesine ortaya koymak nicel araştırmalar yolu ile mümkün değildir. İleride bu konuda çalışma yapacak araştırmacıların okul kademeleri arasındaki bu farklılı̆̆ın nedenleri üzerinde durmaları alan yazına katkı sağlayacaktır.

Yazar Katkı Oranı Beyanı: Tüm yazarlar çalışmaya eşit oranda katkı sağlamıştır.

Etik Kurul Raporu: Araştırmada veri kaynağı olarak dokümanlar kullanıldığından etik kurul raporu alınmamıştır.

Çıkar Çatışası Beyanı: Yazarlar herhangi bir çıkar çatışması beyan etmemişlerdir. 


\section{KAYNAKÇA / REFERENCES}

* Meta-Analize Dâhil Edilen Çalışmalar İçin

*Abdurrezzak, S. (2015). Etkili okul ve okul liderliğine ilişkin öğretmen algılarının incelenmesi. [Yayınlanmamış Yüksek Lisans Tezi]. Cumhuriyet Üniversitesi.

Akgül, Ö. S. (2014). Okul yöneticilerinin bilgi yönetimi becerilerinin örgütsel öğrenme düzeyi ve okuletkililiği ile ilişkisi. [Yayınlanmamış Yüksek Lisans Tezi]. Zirve Üniversitesi.

Alanoğlu, M. (2014).Ortaöğretim kurumlarının örgütsel öğrenme düzeylerinin okul etkililĭği ve örgütsel vatandaşlık davranışlarına etkisi. [Yayınlanmamış Yüksek Lisans Tezi]. Fırat Üniversitesi.

Altun, B. ve Sarpkaya, R. (2017). Eğitim yönetiminde politik modeller. Adnan Menderes Üniversitesi Eğitim Fakültesi Ĕ̆itim Bilimleri Dergisi, 8(2), 1-12.

Arslantaş, H. İ. ve Özkan, M. (2014). Öğretmen ve yönetici gözüyle etkili okulda yönetici özelliklerinin belirlenmesi. The Journal of Academic Social Science Studies, 26(2), 181-193.

*Atılkan, N. (2019). Okul Müdürünün Dağıtımcı Liderlik Davranışları İle Okulların Etkililiği Arasındaki İlişkinin İncelenmesi [Yayınlanmamış Yüksek Lisans Tezi].

Karabük Üniversitesi.

Aydın, A. ve Sarıer, Y. (2013). Eğitim kurumu müdürlerinin liderliği ile okul çıktıları arasındaki ilişkilerin meta-analiz yöntemiyle incelenmesi. Abant İzzet Baysal Üniversitesi Ĕ̆itim Fakültesi Dergisi, 13(2), 257-275.

Bakan, İ., Erşahan, B., Büyükbeşe, T., Doğan, İ. F., ve Kefe, İ. (2015). Dönüşümcü ve etkileşimci liderlik ile öğretmenlerin tükenmişlik düzeyleri arasındaki ilişki. International Journal of Economic \& Administrative Studies, 7(14), 202-222.

Balc1, A. (2002). Etkili Okul ve Okul Geliştirme. Pegem Yayınları.

Başol, G. (2016). Türkiye örnekleminde meta-analiz çalışmalarının içerik analizi ve metodolojik değerlendirilmesi. Journal of Human Sciences, 13(1), 1395-1401.

*Baştoklu, H. (2015). Okul müdürlerinin öğretimsel liderlik davranışları ile okul etkililiği arasındaki ilişkinin incelenmesi [Yayınlanmamış Yüksek Lisans Tezi]. Mevlana Üniversitesi.

Başusta, N. B. ve Gelbal, S. (2015). Gruplararası karşılaştırmalarda ölçme değişmezliğinin test edilmesi: PISA öğrenci anketi örneği. Hacettepe Üniversitesi Eğitim Fakültesi Dergisi, 30(4), 80-90.

Berman, N. G. ve Parker, R. A. (2002). Meta-analysis: Neither quick nor easy. BMC Medical Research Methodology, 2, 1-9.

*Bildirici, S. (2020). Okul etkililiğinin işten ayrılma niyeti üzerine etkisinde paylaşılan liderliğin aracılık rolü [Yayınlanmamış Yüksek Lisans Tezi]. Gaziantep Üniversitesi.

Bolanle, A. O. (2013). Principals' leadership skills and school effectiveness: The case of South Western Nigeria. World Journal of Education, 3(5), 26-33.

Borenstein, M., Hedges, L. V., Higgins, J. P., \& Rothstein, H. R. (2013). Meta analize giriş. (S. Dinçer, Çev.). Anı Yayıncılık.

Brookover, W., Beady, C., Flood, P., Schweitzer, J., \& Wisenbaker, J. (1977). Schools can make a difference. Michigan State University.

Buluç, B. (2009). Sınıf öğretmenlerinin algılarına göre okul müdürlerinin liderlik stilleri ile örgütsel bağlılık arasındaki ilişki. Kuram ve Uygulamada Eğitim Yönetimi, 57(57), 5-34.

*Cansoy, R. ve Parlar, H. (2018). Okul etkililiğinin bir yordayıcısı olarak öğretmen liderliği. Kastamonu Ĕ̆itim Dergisi, 26(3), 925-934.

Cemaloğlu, N. (2009). Okul yöneticilerinin liderlik stillerinin farklı değişkenler açısından incelenmesi. Türk Ĕ̆itim Bilimleri Dergisi, 5(1), 73-114. 
${ }^{*}$ Cerit, Y. ve Yıldırım, B. (2017). İlkokul müdürlerinin etkili liderlik davranışları ile okul etkililiği arasındaki ilişki. Bartın Üniversitesi Ĕ̆itim Fakültesi Dergisi, 6(3), 902-914.

Cheng, Y.C. (1997). School re-engineering in the new century: An organizational perspective. Educational Research Journal, 12(1), 73-95.

Cheng, Y.C. (1996). The improvement of school management: Theory, reform, and practice. Hong Kong Institute of Educational Research.

Cohen, L., Manion, L., \& Morrison, K. (2007). Research methods in education. Routledge-Falmer.

Coleman, J.S., Campbell, E.Q., Hobson, C.J., McPartland, F., Mood, A.M., Weinfeld, G.D., \& York. R.L. (1966). Equality of Educational Opportunity. U.S. Government Printing Office. doi:10.3102/00028312005002260

Çek, F. (2011). Bă̆ımsız anaokulu ve ilköğretim okulu müdürlerinin kültürel liderlik davranışları ile okul öncesi öğretmenlerinin iş doyumu arasındaki ilişki. [Yayınlanmamış Doktora Tezi]. Dokuz Eylül Üniversitesi.

Çelikdemir, K. (2020). Kırsal ve kentsel bölgelerdeki eğitsel farklılıklar. (TEDMEM) https:// ted mem.org/mem-notlari/degerlendirme/kirsal-kentsel-bolgelerdeki-egitsel-farkliliklar.

Erişim tarihi: 25.06.2020.

Çetinkaya, H. (2017). Okul yöneticilerinin toksik (zehirli) liderlik davranışlar ile öğretmenlerin tükenmişlik düzeyleri arasındaki ilişsi [Yayınlanmamış Yüksek Lisans Tezi]. Pamukkale Üniversitesi.

Çiftçi, K. (2019). Ortaokul öğrencilerinin pozitif psikolojik sermaye düzeyler ile okul etkinliği düzeyleri arasındaki ilişki [Yayınlanmamış Yüksek Lisans Tezi]. Sakarya Üniversitesi.

Çobanoğlu, F. (2008). İlköğretim Okullarında örgütsel kimlik ve örgütsel etkililik (Yayımlanmamış Doktora Tezi). Hacettepe Üniversitesi.

Çobanoğlu, F., \& Badavan, Y. (2017). Başarılı okulların anahtarı: etkili okul değişkenleri. Pamukkale Üniversitesi Sosyal Bilimler Enstitüsü Dergisi, (26),114-134.

Çogaltay, N., Yalcin, M., \& Karadag, E. (2016). Educational leadership and job satisfaction of teachers: A meta-analysis study on the studies published between 2000 and 2016 in Turkey. Eurasian Journal of Educational Research, 16(62).

Çulha, Y. (2017). Okul psikolojik danışmanlarının müdürlerinin liderlik stillerini algıları ile kendi iş doyumu ve tükenmişlik düzeyleri arasındaki ilişkinin incelenmesi [Yayınlanmamış Yüksek Lisans Tezi]. Maltepe Üniversitesi.

Dağdelen, S. (2013). Biyoloji derslerinde öğretmenlerin kişilerarası davranışı, sını öğrenme ortamı ve öğrenci başarısı arasındaki ilişkinin incelenmesi [Yayınlanmamış Yüksek Lisans Tezi]. Marmara Üniversitesi.

*Delice, A. (2020). Yöneticilerin paternalist liderlik özellikleri ile okulların etkililiği arasındaki ilişki (Kahramanmaraş ili örneği [Yayınlanmamış Yüksek Lisans Tezi]. Kahramanmaraş Sütçü İmam University.

Dinçer, S. (2021). Eğitim bilimlerinde uygulamalı meta analiz (3. Baskı). Pegem A.

Edmonds, R. (1979). Effective schools for the urban poor. Educational Leadership, 37, 15-18, 20-24.

*Ermeydan, M. (2019). Öğretmen görüşlerine göre okul yöneticilerinin liderlik stilleriyle algılanan okul etkililiği arasındaki ilişki [Yayınlanmamış Yüksek Lisans Tezi]. Kahramanmaraş Sütçü İmam Üniversitesi.

Engin, A. O., Özen Ş. ve Bayoğlu, V. (2009). Öğrencilerin okul öğrenme başarılarını etkileyen bazı temel değişkenler. Sosyal Bilimler Enstitüsü Dergisi, 3, 125-156.

*Eren, A. (2020). Illkokul müdürlerinin öğretimsel liderlik davranışları ile etkili okul arasındaki ilişki [Yayınlanmamış Yüksek Lisans Tezi]. Gazi Üniversitesi. 
Ereş, F. ve Akyürek, M. İ. (2016). İlkokul müdürlerinin dağıtılmış liderlik davranışları ile öğretmenlerin iş doyumu algıları arasındaki ilişki. Gazi Üniversitesi Gazi Ĕ̆itim Fakültesi Dergisi, 36(3), 427-449.

Field, A. P., \& Gillett, R. (2010). How to do a meta-analysis. British Journal of Mathematical \& Statistical Psychology, 63(3), 665-694. doi:10.1348/000711010×502733

Guthrie, J.W. (1970) A survey of school effectiveness studies. In A. M. Mood (Ed.) In Do Teachers Make a Difference? (pp. 25-54). U.S. Government Printing Office.

Günal, Y. (2014). Etkili okul değişkenlerinin öğrenci başarısı ile ilişkisi ve okul hesapverebilirliği [Yayınlanmamış Doktora Tezi]. Ankara Üniversitesi.

Hallinger, P., \& Murphy, J. (1985). Assessing the instructional management behavior of principals. The elementary school journal, 86(2), 217-247.

Hallinger, P. and Heck, P. (1999). Can Leadership Enhance School Effectiveness. In T. Bush, R. Glatter, R. Bolam, P. Ribbins and L. Bell (eds) Redefining Educational Management, (pp. 178-90). London: Paul Chapman

Hallinger, P., \& Heck, R. H. (1996). Reassessing the principal's role in school effectiveness: A review of empirical research, 1980-1995. Educational administration quarterly, 32(1), 5-44.

Hallinger, P., \& Walker, A. (2017). Leading learning in Asia-Emerging empirical insights from five societies. Journal of Educational Administration, 55(2), 130-146.

Harbaugh, R. J.(2005). Examining the correlates of effective schools present in an intermediate school: A case study [Yayımlanmamış Doktora Tezi]. Immaculate University.

Higgins, J. P. T., \& Green, S. (Eds). (2011). Cochrane handbook for systematic reviews of interventions. http://handbook-5-1.cochrane.org/

Hoy, W. K., \& Ferguson, J. (1985). A theoretical framework and exploration of organizational effectiveness in schools. Educational Administration Quarterly, 21,117-134. doi: $\underline{10.1177 / 0013161 \times 85021002006}$

${ }^{*}$ Işik, A. N. (2020). Ethical leadership and school effectiveness: The mediating roles of affective commitment and job satisfaction. International Journal of Educational Leadership and Management, 8(1), 60-87.

İnce, C. (2017,Oct 27-29). Öğrenci başarısı üzerinde okulun etkisi hakkında bir değerlendirme [sözlü sunum]. International Conference on Multidisciplinary, Engineering, Science, Education and Technology. Bitlis, Turkey.

Kalkan, F. (2020). Öğretmenlerin öz yeterlik inançları ve iş doyumu düzeyleri arasındaki ilişki: Bir meta analiz çalışması. Ĕ̆itim ve Bilim, 45(204), 317-343.

${ }^{*}$ Kılıç, F. (2017). Bilim ve sanat merkezlerindeki öğretmelerin yöneticilerinin liderlik yeterlilikleri, kurum etkililiği ve kurum kültürüne yönelik algıları arasındaki ilişki [Yayımlanmamış doktora tezi]. Abant İzzet Baysal Üniversitesi.

*Kocak, S. ve Bozkurt Bostanci, A. (2020). “Does public leadership improve school effectiveness through strengthening teacher professionalism?". Eurasian Journal of Educational Research, 90, 19-44.

Korkmaz, M., Baimukhanbetov, B., Abdillayev, A.K., Serik, Aknazarov, B., \& Nyshanova, S.T. (2014). Teacher and classroom context effects on academic achievement of primary school students. Life Science Journal, 11(1), 233-240.

Küçüközkan, Y. (2015). Liderlik ve motivasyon teorileri: Kuramsal bir çerçeve. Uluslararası Akademik Yönetim Bilimleri Dergisi, 1(2), 85-116.

Laila, A. (2015). The effective school: The role of the leaders in school effectiveness. Educational Research and Reviews, 10(6), 695-721.

Levin, H. M. (1970). A new model of school effectiveness. In A. Mood (Ed.), Do teachers make a difference? (pp. 55-78). U.S. Office of Education.. U.S. Government Printing Office. 
Lezotte, L. W. (1993). Creating effective schools today and tomorrow. Journal for Quality and Participation. 16, 1, 22-30.

Lunenburg, F. C., \& Ornstein, A. C. (2013). Eğitim yönetimi (G., Arastaman, Çev.). Nobel Akademik Yayıncilık.

Marzano, R. J. (2012). Teaching self-efficacy with personal projects. Educational Leadership, 69(8), 86-87.

McNamara, D. (1968). The principal's personal leadership style, the school staff leadership situation, and school effectiveness [Unpublished doctoral thesis] University of Alberta.

*Namlı, A. (2017). Lise müdürlerinin destekleyici liderlik davranışlarının ve kolektif güvenin okul etkililiği üzerindeki etkisi [Yayımlanmamış doktora tezi]. Fırat Üniversitesi.

*Nartgün, Ş. S., Limon, İ., \& Dilekçi, Ü. (2020). The relationship between sustainable leadership and perceived school effectiveness: the mediating role of work effort. Bartın University Journal of Faculty of Education, 9(1), 141-154.

Neufeld, B., Farrar, E. \& Miles, M.B. (1983). Reviews of effective schools programs: the lessons for secondary schools. Center for Policy Research, Huron Institute.

OECD. (2016). PISA 2015 Results (Volume II): Policies and Practices for Successful Schools. OECD Publishing. doi: 10.1787/9789264267510

OECD. (2018). OECD school user survey: Improving learning spaces together. http://www.oecd.org/education/OECD-School-User-Survey-2018.pdf

Oğuz, E. (2011). Öğretmenlerin örgütsel vatandaşlık davranışları ile yöneticilerin liderlik stilleri arasındaki ilişki. Kuram ve Uygulamada Ĕ̆itim Yönetimi, 3(3), 377-403.

Oldaç, Y. İ. (2016). The relationship between distributed leadership, enabling school structure, teacher collaboration, academic optimism and student achievement: a school effectiveness model [Yayımlanmamış yüksek lisans tezi]. Orta Doğu Teknik Üniversitesi.

Önder, E. ve Tulunay Ateş, Ö. (2017). Öğretmenlerin örgütsel adalet algıSı ve örgütsel bağl1lıkları arasındaki ilişkiler: Türkiye'de yapılmış çalışmaların meta analizi. Turkish Studies, International Periodical for the Languages, Literature and History of Turkish or Turkic, 12(25), 589-608.

Özdemir, Servet. (2000). Egitimde Örgütsel Yenilesme. (5. Baskı). Pegem

Özdemir, S. ve Sezgin, F. (2002). Etkili okullar ve öğretim liderliği. Kırgızistan Türkiye Manas Üniversitesi Sosyal Bilimler Dergisi, 3, 266-282.

Özdoğru, M. ve Güçlü, N. (2020). Okul yöneticilerinin öğretimsel liderlik davranışlarının okul çıtılarına etkisinin meta-analiz yöntemiyle incelenmesi. Anadolu University Journal of Education Faculty, 4(2), 88-103.

Özer, Y. ve Anıl, D. (2011). Öğrencilerin fen ve matematik başarılarını etkileyen faktörlerin yapısal eşitlik modeli ile incelenmesi. Hacettepe Üniversitesi Ĕ̆itim Fakültesi Dergisi, 41, 313 -324. doi:10.17755/esosder.391299

Özgenel, M.(2020). An organizational factor predicting school effectiveness: school climate. International Journal of Psychology and Educational Studies, 7(1), 38-50.doi:10.17220/ ijpes.2020.01.004

*Özkan, Y. (2014). Okul yöneticilerinin liderlik stilleri ile okulların etkililik düzeyleri arasındaki ilişkinin incelenmesi [Yayınlanmamış Yüksek Lisans Tezi]. Mevlana Üniversitesi.

Özkan, M. (2016). Liderlik hangi sıfatları, nasıl alıyor? Liderlik konulu makalelerin incelenmesi. Gaziantep Üniversitesi Sosyal Bilimler Dergisi, 15(2), 615-639.

Polat, S. (2009). Akademik başarısızlığın toplumsal eşitsizlik temelinde çözümlenmesi. Eğitim Bilim Toplum Dergisi, 7 (25), 46-61.

Polatcan, M. ve Cansoy, R. (2018). Türkiye'de etkili okul araştırmaları: Ampirik araştırmaların analizi. Sakarya University Journal of Education, 8(3), 8-24. 
Reid, K, Hopkins, D., \& Holly, P (1987). Towards the Effective School. Blackwell.

Reynolds, D. (1985), Studying School Effectiveness. The Falmer Press.

Rosenthal, R. (1979). The 'file drawer' problem and tolerance for null results. Psychological Bulletin, $86,638-641$.

Sammons, P., Hillman, J., \& Mortimore, P. (1995). Key Characteristics of Effective Schools: A Review of School Effectiveness Research. Institute of Education, University of London.

Sergiovanni, T. J. (2006). The principalship: A reflective practice perspective (5th ed.). Allyn and Bacon. Sönmez K. (2017). Türkiye'de Yönetim Becerileri ve Liderlik (2.Baskı). Anı Yayınları.

Şişman, M. (1996). Etkili okul yönetimi (Yayınlanmamış Araştırma Raporu). Eskişehir Osmangazi Üniversitesi.

Şişman, M. (2020). Eğitimde mükemmellik arayışı etkili okullar (6. Baskı). Pegem A Yayıncılık.

Şişman, M. (2018). Ögretim liderligi [İnstructional leadership] (6. Baskı). Pegem A Yayıncllı.

Şen, S. ve Yıldırım, İ. (2020). CMA ile meta-analiz uygulamaları. Anı Yayıncilık.

Şenel, T. ve Buluç, B. (2016). İlkokullarda okul iklimi ile okul etkililiği arasındaki ilişki. TÜBAV Bilim Dergisi, 9(4), 1-12.

Tatlah, I. A., \& Iqbal, M. Z. (2012). Leadership styles and school effectiveness: Empirical evidence from secondary level. Procedia-Social and Behavioral Sciences, 69, 790-797.

*Tuncel, H. (2013). Etkili okul oluşturmada okul müdürünün dönüşümcü liderlik rolü.[Yayınlanmamış Yüksek Lisans Tezi]. Erciyes Üniversitesi.

Turan, S. ve Bektaş, F. (2014). Liderlik. S. Turan (Ed.), Eğitim yönetimi, teori, araştırma ve uygulama. Pegem Akademi.

Turan, S. (2020). Liderlik Nedir? K. Yılmaz (Ed.), Liderlik: kuram - araştırma - uygulama içinde (s.16). Pegem Akademi.

Turhan, M., Şener, G. ve Gündüzalp, S. (2017). Türkiye'de okul etkililiği araştırmalarına genel bir bakış. Turkish Journal of Educational Studies, 4(2), 103-151.

Uğurlu, C. T. ve Üstüner, M. (2011). Öğretmenlerin örgütsel bağl1lık düzeylerine yöneticilerinin etik liderlik ve örgütsel adalet davranışlarının etkisi. Hacettepe Üniversitesi Eğitim Fakültesi Dergisi, 41(41).

Ünal, A. ve Çelik, M. (2013). Okul yöneticilerinin öğretimsel liderlik davranışı ile öğretmenlerin örgütsel vatandaşlık davranışlarının analizi. Uşak Üniversitesi Sosyal Bilimler Dergisi, 6(2), 239-258.

Yaşbay, H. (2011). Otantik liderlik ve örgütsel bağlllık ilişkisi [Yayımlanmamış Yüksek Lisans Tezi]. Dokuz Eylül Üniversitesi.

Yeşil, S. (2013). Kültür ve kültürel farkliliklar: liderlik acısından teorik bir değerlendirme. Elektronik Sosyal Bilimler Dergisi, 12(44), 52-81.

*Yılmaz, E. (2010). İlköğretim okulu müdürlerinin öğretimsel liderlik rolleri ile etkili okul arasındaki ilişkinin değerlendirilmesi [Yayımlanmamış yüksek lisans tezi]. Gazi Üniversitesi.

Yılmaz, A. ve Boğa Ceylan, Ç. (2011). İlköğretim okul yöneticilerinin liderlik davranış düzeyleri ile öğretmenlerin iş doyumu ilişkisi. Kuram ve Uygulamada Egitim Yönetimi Dergisi, 17(2), 277-394.

Yirci, R. ve Berk, B. (2021). Okul yöneticilerinin ve öğretmenlerin görüşlerine göre etkili okul müdürü: nitel bir araştırma. Journal of History School (JOHS), 50, 570-598.

*Yörük, S. ve Şahin, B. (2012). Cultural leadership roles of school principals in high schools as effective schools. Journal of Theoretical Educational Science, 5(3), 352-368.

Yukl, G. (2010). Leadership in Organisations. Prentice Hall.

*Yumlu, E. (2020). Okul Yöneticilerinin Sahip Oldukları Teknolojik Liderlik Yeterlilikleri İle Okul Etkililiği Arasındaki İlişkinin İncelenmesi [Yayımlanmamış yüksek lisans tezi]. Marmara Üniversitesi. 
*Zembat, R., Koçyiğit, S., Tuğluk, M. N., \& Doğan, H. (2010). The relationship between the effectiveness of preschools and leadership styles of school managers. Procedia-Social and Behavioral Sciences, 2(2), 2269-2276. 